\title{
REVIEWS
}

\section{The mechanisms and potential of stem cell therapy for penile fibrosis}

Uros Milenkovic ${ }^{1}$, Maarten Albersen ${ }^{*}$ and Fabio Castiglione $e^{1,2,3}$

Abstract | Fibrosis is often caused by chronic tissue injury leading to a persisting inflammatory response with excessive accumulation of extracellular connective tissue proteins. Peyronie's disease, urethral stricture and penile (corpora cavernosa) fibrosis are localized fibrotic disorders of the penile connective tissues that can substantially impair a patient's quality of life. Research over the past few decades has revealed the ability of stem cells to secrete a wide range of paracrine factors, a characteristic that could be exploited therapeutically to prevent and treat several inflammatory and fibrotic diseases. In preclinical studies, mesenchymal stem cells (MSCs) have proven to be the most effective and readily available type of stem cells for therapeutic use. An important advantage of MSCs is their ability to circumvent the immune system and function as immunomodulatory 'drug stores' to influence multiple cell types simultaneously. Many studies using stem cells have been applied exclusively to corpora cavernosa fibrosis owing to its well-established disease models. A plethora of preclinical data suggest the benefit of stem cells for use in penile fibrosis. However, their exact mechanism of action and optimal timing and mode of administration must be determined before clinical translation.

Tunica albuginea The connective tissue sheath surrounding the erectile tissue (corpora cavernosa) of the penis.

Corpora cavernosa Sponge-like regions of the erectile tissue that contain most of the blood during a penile erection. (Singular: corpus cavernosum).
'Laboratory for Experimental Urology, Organ Systems, Department of Development and Regeneration, University of Leuven, Leuven, Belgium.

${ }^{2}$ The Institute of Urology, University College of London Hospital (UCLH), London, UK.

${ }^{3}$ Division of Oncology/Unit of Urology, Urological Research Institute, IRCCS Ospedale San Raffaele, Milan, Italy.

*e-mail: maarten.albersen@ uzleuven.be

https://doi.org/10.1038/ s41585-018-0109-7
Fibrosis is a wound-healing disorder that often occurs in response to chronic tissue injury and that is defined by a persisting inflammatory reaction and the subsequent excessive accumulation of extracellular connective tissue proteins such as collagen, elastin and fibronectin (collectively termed the extracellular matrix $(\mathrm{ECM}))^{1,2}$. Typically, inflammation and ECM aggregation is an essential and reversible phase of the normal wound-healing process ${ }^{3}$. However, if the initial injury (for example, infection, mechanical stress or autoimmune reaction) is not resolved in a timely manner or the wound-healing process itself becomes deregulated, this phase can gradually evolve into a permanent fibrotic reaction and lead to fibrogenesis, a process termed 'fibrosis'4. Importantly, fibrosis is the conclusive pathological consequence of many chronic inflammatory disorders and can lead to a progressive loss of tissue and/or organ function ${ }^{5}$.

Localized fibrotic disorders of the penile connective tissues such as Peyronie's disease ${ }^{6-8}$ and urethral stricture disease ${ }^{9}$ are thought to occur as a result of impaired wound healing. Peyronie's disease is considered to be caused by lesions in the tunica albuginea following intercourse-related repetitive microtrauma caused by buckling of the penis, whereas urethral strictures can be caused by trauma to the urethra as a result of instrumentation (iatrogenic: bladder catheters) and/or infectious and inflammatory disorders (for example, sexually transmitted diseases ${ }^{8,9}$. Penile fibrosis occurs as a diffuse fibrotic process in the corpora cavernosa of the penis and is the result of various conditions associated with erectile dysfunction (ED) such as diabetes mellitus, atherosclerosis, iatrogenic pelvic nerve damage (after radical prostatectomy for prostate cancer) and even ageingrelated $\mathrm{ED}^{8}$. Additionally, severe corporal fibrosis can occur acutely, in which case it is frequently the result of episodes of ischaemic priapism ${ }^{10}$. These fibrotic disorders can severely decrease the quality of life of patients by causing lower urinary tract symptoms (LUTS), the onset or worsening of ED, painful and deformed erections, major depressive disorders and relationship issues ${ }^{11,12}$.

At present, very few therapeutic strategies are available for the treatment of fibrotic conditions; however, the search for novel treatments has led to the discovery of the immunomodulatory capacities of stem cells. Stem cells are well known for their ability for self-renewal and differentiation into a diverse set of mature cell populations ${ }^{12}$. Moreover, the secretion of a wide range of paracrine factors, including growth factors, cytokines, chemokines and even functional small RNAs (via extracellular vesicles), makes stem cells appealing for therapeutic application. These secreted factors enable stem cells to influence and modify their host environment, particularly during and early after tissue injury ${ }^{13-15}$. In recognition of these unique properties, a growing body of (preclinical) evidence has demonstrated the potential 


\section{Key points \\ - Fibrosis is a state of excessive wound-healing leading to the replacement of the local parenchyma with stiff and afunctional extracellular matrix, resulting in loss of organ function in advanced stages. \\ - Owing to the complex network of cell types and interactions involved in fibrosis, very few effective medical treatment options are currently available for patients with fibrotic diseases, including penile fibrosis. \\ - Stem cells can interrupt several key processes in the fibrotic cascade simultaneously and, therefore, have great potential as novel antifibrotic therapies. \\ - Penile fibrosis can occur in the corpora cavernosa, tunica albuginea or urethra. \\ - A large number of preclinical studies have investigated the effect of stem cells for the treatment of penile fibrosis, and have reported encouraging results. \\ - Certain limitations (such as isolation, timing, administration and dosage) need to be addressed before preclinical findings can be translated into the clinical setting.}

\section{Priapism}

A condition whereby the penis remains in an erectile state without any stimulation, or after the stimulation has

ended, for more than 4 hours.

Mesenchymal stem cells (MSCs). Multipotent stromal cells with the ability to differentiate into several cell types within their germ layer (osteoblasts, chondrocytes, myocytes and adipocytes).

Corpus spongiosum

Spongy tissue surrounding the male urethra within the penis.

\section{Totipotent stem cells}

These stem cells have the capacity to divide and develop into cells from all three germ cell layers and into extraembryonic tissues (for example placenta). The zygote is an example of such a cell.

Pluripotent stem cells These stem cells have the capacity to divide and develop into cells from all three germ cell layers, but not into extraembryonic tissues (for example, placenta). Embryonic stem cells are examples of such cells.

Multipotent stem cells These stem cells have the capacity to divide and develop into cells from a specific tissue or organ. Most adult stem cells are examples of such cells. therapeutic role of stem cells in alleviating fibrosis ${ }^{16-20}$. Mesenchymal stem cells (MSCs) have been commonly used in this therapeutic context and have been shown to have a role in reducing fibrosis in animal models of lung $^{21,22}$, liver ${ }^{23-25}$, kidney $^{26-28}$, heart ${ }^{29,30}$, corpus spongiosum and urethra ${ }^{31}$, corpus cavernosum ${ }^{32,33}$ and tunica albuginea $^{34}$ fibrosis. As of September 2018, 60 clinical trials (active or recruiting) are evaluating the efficacy of MSCs for the treatment of various fibrotic disorders (for example, hepatic, Crohn's disease-related intestinal, cardiac and pulmonary fibrosis).

The precise mechanisms governing the antifibrotic properties of MSC therapy are yet to be elucidated. However, the leading theory is that MSCs function as 'drug-stores', influencing several cell types (for example, cells from the innate and adaptive immune system, resident fibroblasts and smooth muscle cells) and the production of several profibrotic and antifibrotic factors simultaneously ${ }^{12}$. Most preclinical studies suggest that MSCs exert their antifibrotic functions through immunomodulation, thereby limiting the host's response to injury and preventing the onset of fibrosis ${ }^{12,15}$. Another putative mechanism is the attenuation of profibrotic phenotypic changes of resident fibroblasts into the contractile and ECM-producing myofibroblasts ${ }^{35}$. Furthermore, stem cells can directly modulate ECM composition on the basis of their ability to secrete high levels of matrix metalloproteinases (MMPs) and other matrix-modulating enzymes (for example, through inhibition of tissue inhibitors of metalloproteinases (TIMPs) $)^{15}$. Nonetheless, these hypotheses have not yet been proven and additional studies focusing on the mechanisms of MSC function are ongoing ${ }^{12,15}$.

In the past decade, stem cells have also been evaluated for the prevention and treatment of fibrosis of the male genitourinary tract (Peyronie's disease, urethral stricture and corpora cavernosa fibrosis). In this Review, we provide an overview of current research on stem cells for the treatment of penile fibrosis, with an emphasis on the specific mechanisms of antifibrotic activity.

\section{Pathophysiology of fibrotic disorders}

Fibrotic diseases embody a spectrum of disorders (pulmonary, renal, hepatic, cardiac and dermal fibrosis) that are characterized by an excessive accumulation of $\mathrm{ECM}^{3}$. Fibrosis is considered to be the result of an abnormal wound-healing process, and is often the end stage of disorders caused by chronic tissue injury and inflammation $^{36,37}$. Wound-healing is an intricate and finely tuned process that involves the coordinated production of growth factors, cytokines, ECM proteins and crosstalk between many cell types. This process is divided into four steps that are tightly regulated - haemostasis, inflammation, proliferation and remodelling ${ }^{2}$ (FIG. 1). Fibrosis is characterized by the disproportionate accumulation of ECM components, such as interstitial collagens (types I and III), cellular fibronectin, elastin and basal membrane proteins (such as laminin and collagen IV) ${ }^{5}$. The fibrotic process is driven by a complex and ubiquitous molecular pathway that is shared by all fibrotic diseases, regardless of the aetiology, trigger or organ affected ${ }^{1,2,17,37-39}$ (FIC. 1). However, the precise mechanism remains poorly understood despite extensive study. The intricate interplay between the innate and acquired immune system and resident cell types within a tissue (for example, endothelial cells, pericytes and fibroblasts) makes the fibrotic process difficult to study owing to a lack of in vitro models mimicking these interactions and the fact that in vivo models do not sufficiently represent the human disease ${ }^{17,39,40}$. Furthermore, tissue resection and surgical intervention is rarely required in the clinical context (in contrast to cancer), leading to inadequate characterization of the fibrotic process. These limitations have had important repercussions in the search for a common and effective treatment for fibrotic disorders. To date, only a few drugs targeting fibrosis are clinically available (for example, nintedanib and pirfenidone for idiopathic lung fibrosis). However, their use is usually limited owing to their modest clinical effects and/or unfavourable toxicity profiles, leading to a considerable proportion of patients who do not receive therapy ${ }^{3,41,42}$.

Two presentations are common in patients with penile fibrosis. Patients might present with a fibrous plaque that develops in the tunica albuginea in Peyronie's disease or corpora cavernosa fibrosis, both of which can lead to ED, or with fibrosis of the corpus spongiosum, which is responsible for urethral strictures (spongiofibrosis) (FIC. 2). These processes differ in their aetiology, time course and treatment, but have many features in common with other fibrotic disorders that develop through similar molecular pathways (such as activation of the fibrin cascade leading to chemotaxis of macrophages and other cells of the innate immune system, together with induction of a phenotypic switch of resident fibroblasts into profibrotic myofibroblasts) ${ }^{8}$.

\section{Stem cells}

Stem cells are capable of self-renewal and their potential for differentiation can give rise to mature cell populations. Depending on the environmental conditions, stem cells can follow different paths of differentiation; they can remain in a dormant (quiescent) state, undergo apoptosis or elicit cell division to yield either two daughter stem cells, one daughter stem cell and one differentiated cell, or two differentiated cells $s^{43,44}$.

Depending on their potential for differentiation, stem cells are classified as totipotent stem cells, pluripotent stem cells or multipotent stem cells. The stem 
cells of the morula have totipotent characteristics and can differentiate into any completely differentiated organ or extra-embryonic tissue. Embryonic stem cells (ESCs) are pluripotent and have the ability to produce all germinal layers ${ }^{45,46}$, whereas multipotent stem cells (such as MSCs; also termed multipotent stromal cells) can be isolated from organs and can differentiate into any cell type within their germ tissue ${ }^{47}$. ESCs have two main advantages over MSCs, the first of which is their ability to proliferate for longer periods of time, and the second is their capacity to differentiate into a broader range of cell types. However, owing to the ethical conflict that surrounds ESCs, their use in research has been limited and, as such, MSCs are a more feasible option for research and therapeutic applications ${ }^{12-15,46}$.

\section{MSCs}

MSCs were first described in 1968 as fibroblast-like cells derived from the bone marrow ${ }^{48}$, and were subsequently isolated from a variety of other adult tissues, including adipose tissue, periosteum, synovial fluid, periodontal ligament, fallopian tube, brain and muscle tissue recovering from injury ${ }^{49}$. A growing body of evidence indicates that a substantial fraction of cells that exhibit the in vitro characteristics of isolated MSCs arise from vascular pericytes in vivo, suggesting that a common precursor cell type exists in a wide variety of adult and fetal tissues ${ }^{17,39,50-53}$.

In the past few decades, many studies have shown that MSCs secrete cytokines that have trophic effects on cells, promoting cytoprotection, cell survival and immunomodulation ${ }^{12}$. Importantly, the therapeutic use of allogenic MSCs does not always require the use of immune suppression. MSC rejection and immunogenicity is poorly understood, but it seems that MSCs do not escape the immune system by default (that is, they are not 'immune privileged'); instead, they create an immunosuppressive environment and evade the immune system by impeding $\mathrm{T}$ cell activation and antigen-presenting cell (APC) maturation ('immune evasive' $)^{54}$. Thus, MSCs that do not manage to tip the balance towards an immunosuppressive state are still detected and destroyed by APCs (like any other allogenic cell), and debris from dead MSCs (either through apoptosis or phagocytosis) can further activate APCs in the context of a danger signal ${ }^{54,55}$.

The considerable therapeutic potential of MSCs has generated increasing interest in a wide variety of biomedical disciplines ${ }^{56}$. However, investigators studying MSCs have used different methods of MSC isolation, expansion and characterization ${ }^{57}$, which has generated a large number of ambiguities and inconsistencies in the field. To address this issue, the Mesenchymal and Tissue Stem Cell Committee of the International Society for Cellular Therapy (ISCT) have proposed minimal criteria to define human MSCs. Specifically, MSCs must be plastic-adherent in standard culture conditions (culture flasks, incubation at $37^{\circ} \mathrm{C}, 5 \% \mathrm{CO}_{2}$ ); express $\mathrm{CD} 105$, CD73 and CD90 on $95 \%$ of the MSC population, and lack expression of CD45, CD34, CD14 or CD11b, CD79 $a$ or CD19, and HLA-DR (also known as CD74) surface molecules on $<2-5 \%$ of the population (on flow cytometry analysis); and have the ability to differentiate into osteoblasts, adipocytes and chondroblasts under standard in vitro differentiating condition $\mathrm{s}^{57}$.

Adult MSCs can differentiate into various types of terminally differentiated daughter cells within the mesodermal lineage ${ }^{58}$. Pluripotent and multipotent stem cells can give rise to hundreds of different cell types through distinct steps of differentiation ${ }^{58}$. Stem cell fate is determined by a complex network of epigenetic, transcriptional and post-transcriptional, and translational and post-translational regulatory mechanisms $^{59,60}$. Importantly, a major role for epigenetic modifications through DNA methylation in the maintenance of dedifferentiated states has become clear. DNA (cytosine-5)-methyltransferase 1 (DNMT1) is an enzyme responsible for DNA methylation (and, therefore, transcriptional inhibition) of DNA regions that are important for cellular differentiation. DNMT1 loss leads to the failure of proliferative self-renewal and premature differentiation of stem cells $s^{59}$. Few studies have investigated the percentage of the stem cell genome that remains methylated once the cells are taken out of their in vivo niche to prepare them for therapeutic application. However, it seems that, when cultured, MSCs have a tendency to maintain their in vivo methylation patterns ( $90 \%$ of unmethylated genes remain unmethylated, and $\sim 60 \%$ of methylated genes remain methylated) ${ }^{59,60}$.

MSC differentiation and secretome. Until about a decade ago, the capacity of MSCs for multipotent division was thought to enable these cells to restore damaged tissues by replacing dysfunctional, damaged or dead cells ${ }^{45,58}$. Additionally, studies have increasingly shown that MSCs release a broad spectrum of regulatory and trophic factors (growth factors, cytokines and chemokines), suggesting a paracrine role for MSCs as 'site-regulated drug stores' in vivo, whereby MSCs can influence the local tissue environment even if they do not engraft or differentiate $\mathrm{e}^{12-14,49,61}$.

Importantly, evidence has accumulated over the past decade to suggest that endogenous MSCs have a crucial role in the regulation of the normal wound-healing process. Specifically, MSCs can accelerate wound contraction and increase the quality of the tissue, counteract healing anomalies and reduce the amount of ECM produced (which contributes to an improved functional and cosmetic result of the scar $)^{51,61-69}$. However, evolutionary natural selection has led to rapid, rather than perfect, healing processes; inefficient endogenous regulation of this process can result in the formation of hypertrophic and debilitating scar tissue (for example, hypertrophic scar formation (keloid), loss of hair follicles after burn wounds or cardiac fibrosis resulting from an ischaemic cardiac event $)^{1,37,70}$. In such instances, preclinical studies have shown that administration of autologous MSCs can shift the balance towards normal wound-healing, indicating that exogenous administration of the body's own MSCs in high concentrations, and at the correct site, can support the endogenous healing process ${ }^{71-75}$. Supported by these observations, researchers have initiated clinical trials in the past decade to exploit the immune-regulatory and paracrine properties of MSCs 


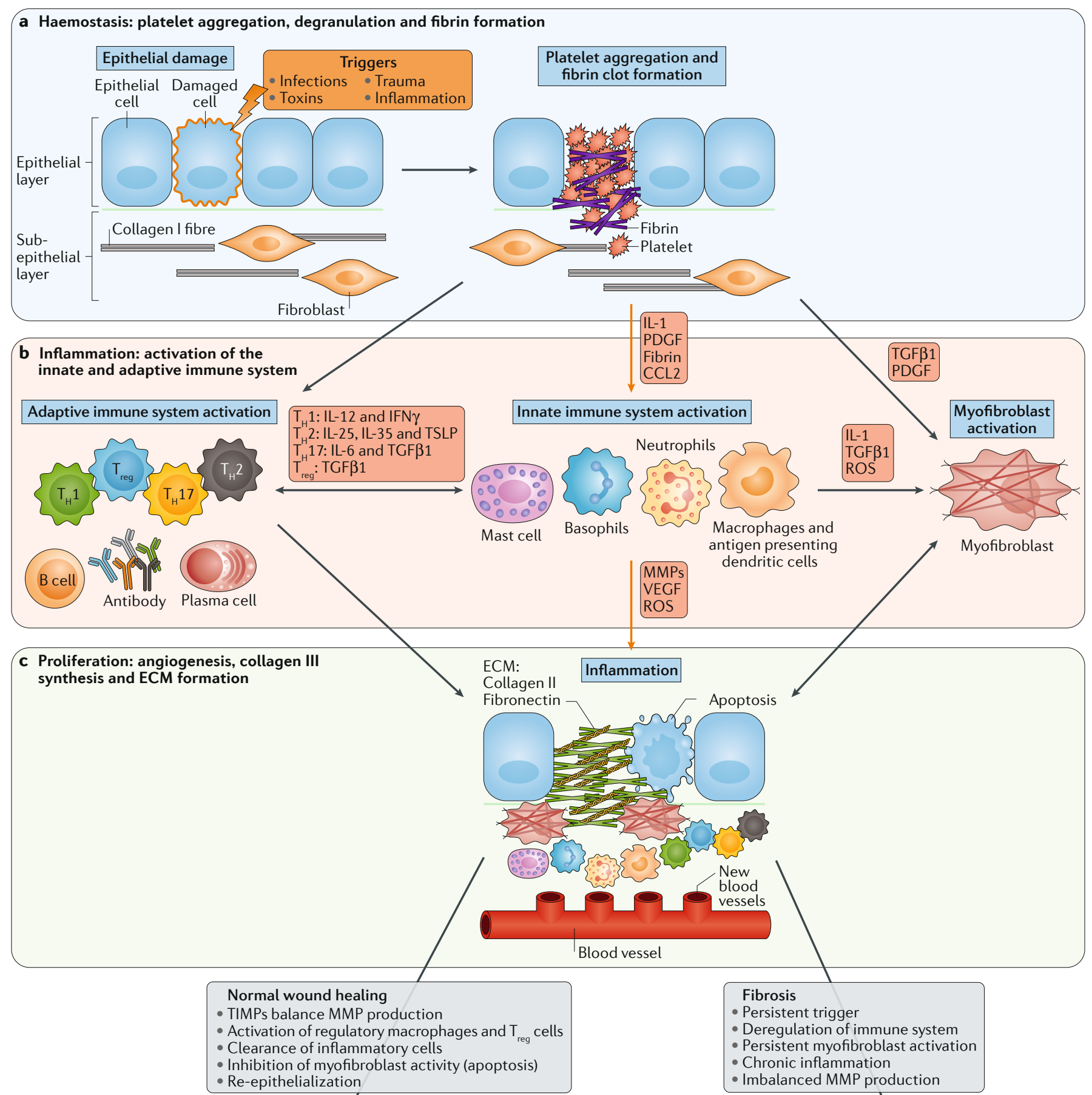

d Remodelling: collagen remodelling, vascular maturation and regression
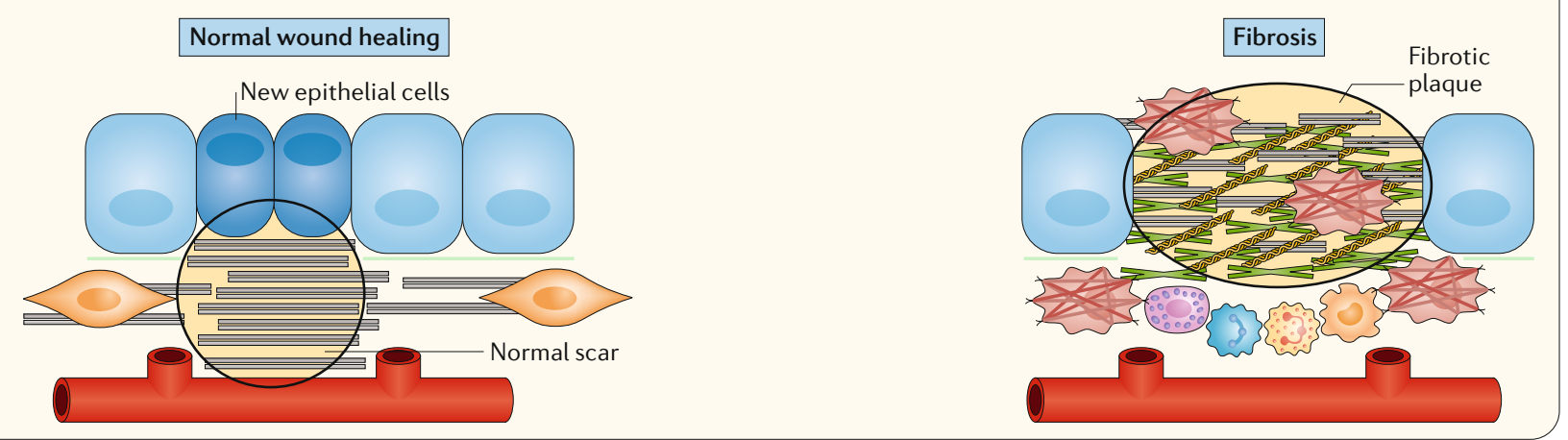
4 Fig. 1 | Overview of the wound-healing process and fibrosis. a During an acute tissue insult, innate immune cells are recruited to restore homeostasis via normal wound healing. During the haemostasis phase, tissue damage activates the coagulation cascade and induces platelet activation and blood clot formation. When the epithelium is damaged, prestored interleukin-1 (IL-1) is released. Moreover, circulating platelets release coagulation factors for haemostasis (fibrin activation); and growth factors, such as platelet-derived growth factor (PDGF), a potent chemoattractant for inflammatory cells and mitogenic factor for myofibroblasts, and transforming growth factor- $\beta 1$ (TGF $\beta 1$ ), which stimulates extracellular matrix (ECM) production and fibroblast-to-myofibroblast transformation ${ }^{1,38,165}$. Aside from its ubiquity in the coagulation cascade, thrombin also activates $\mathrm{C}$ - $\mathrm{C}$ motif chemokine 2 (CCL2) ${ }^{4}$, and myeloid cells (macrophages) migrate from the bone marrow to the site of injury in response to the CCL2 gradient. Together with neutrophils, these cells release a wide array of toxic mediators - reactive oxygen species (ROS) and reactive nitrogen species (RNS) - that exacerbate tissue damage if they are not removed in a timely manner ${ }^{166} . \mathbf{b} \mid$ The inflammation phase is characterized by the chemotaxis and activation of innate immune cells by CCL2, IL-1, PDGF and TGF $\beta 1$. The classic inflammatory macrophage exhibits a strong microbicidal or tumoricidal activity through expression of IL-1 $\beta$, tumour necrosis factor (TNF) and IL-6 (REFS $\left.{ }^{70,167}\right)$. Additionally, macrophages also produce large quantities of TGF $\beta 1$, which has an important role in myofibroblast generation ${ }^{87}$. Local inflammation activates naive (unactivated) T cells of the adaptive immune system towards different phenotypes via various cytokines ${ }^{2}$. Precursor $B$ cells are activated mainly by $T$ cell-dependent cytokines and antigen presentation (although $\mathrm{T}$ cell-independent pathways also exist).

A fully matured B cell becomes a nondividing plasma cell, producing large quantities of antibodies directed against a specific antigen ${ }^{168}$. $\mathbf{c}$ |During the proliferation phase, the immune system — via secretion of cytokines, chemokines and free radicals — attempts to remove the triggering factor while activating the myofibroblasts that regulate angiogenesis and ECM production in normal wound healing ${ }^{169}$. In fibrotic conditions, dysregulation of genes involved in ECM remodelling occurs; for example, downregulation of matrix metalloproteinases (MMPs; which remove excessive collagen fibres) and upregulation of tissue-inhibitors of metalloproteinases (TIMPs; produced by myofibroblasts and macrophages) ${ }^{170-172} \cdot \mathbf{d} \mid$ During the remodelling phase, activated myofibroblasts promote wound contraction. Different collagen types (switch from type III to type I collagen) are produced, blood vessels repaired, excessive scar tissue removed, and epithelial cells divide and migrate over the basal layers to regenerate the epithelium, restoring the damaged tissue to its normal appearance with minimal scar tissue ${ }^{2,37}$.

Failure to effectively eliminate the triggering factors can induce persistent inflammation of the tissue, which leads to fibrosis. A few crucial concepts are generally applicable for the progression of fibrotic disease: persistent chronic tissue injury owing to chronic exposure and/or inflammation; ongoing recruitment of innate and adaptive immune cells to create a profibrogenic environment favouring chronic inflammation; and inefficient remodelling modulated by tissue hypoxia and subsequent neoangiogenesis ${ }^{173,174}$. TSLP, thymic stromal lymphopoietin. $\mathrm{T}_{H}$ cell, T helper cell; $\mathrm{T}_{\text {reg }}$ cell, regulatory $\mathrm{T}$ cell; VEGF, vascular endothelial growth factor.

in several therapeutic scenarios, including fibrotic disease ${ }^{56}$. Notable examples include the attenuation of graft-versus-host disease ${ }^{76}$, immunomodulation in multiple sclerosis ${ }^{77}$, arthritis $^{78}$ and Crohn's disease ${ }^{79}$, and the induction of trophic effects in brain and spinal cord injury $^{80}$ and myocardial infarction ${ }^{81}$.

The precise antifibrotic properties of exogenously administered MSCs are not yet properly understood and are a topic of intensive research ${ }^{82,83}$. A growing body of evidence suggests that MSCs function through a plethora of mechanisms including, but not limited to, immunomodulation of the innate and adaptive immune system, reactive oxygen species (ROS) neutralization and/or scavenging, promotion of angiogenesis, and interaction with the tissues and cells responsible for the fibrotic process (for example, by blocking myofibroblast activation $)^{84}$. Nonetheless, MSCs have been described to exert both profibrotic and antifibrotic effects, depending on the inflammatory setting, dosing and time interval of repeated MSC administration ${ }^{17,35}$. This paradox can be in part explained by the broad immunoregulatory capabilities of MSCs, whereby they can influence both the adaptive and innate immune systems ${ }^{85}$ (FIG. 3).

In the presence of inflammation (high levels of tumour necrosis factor (TNF) and interferon (IFN)- $\gamma$ ), MSCs adopt an immunosuppressive phenotype and secrete high levels of anti-inflammatory and antifibrotic soluble factors, including nitric oxide (NO), prostaglandin E2 (PGE2), interleukin-10 (IL-10), hepatocyte growth factor (HGF), indoleamine 2,3-dioxygenase (IDO) and haem oxygenase $(\mathrm{HO})^{17}$.

$\mathrm{NO}$ is one of the most important antifibrotic agents and functions through the direct inhibition of ECM and transforming growth factor- $\beta 1$ (TGF $\beta 1$ ) production, induction of myofibroblast apoptosis and stimulation of MMP secretion ${ }^{86}$. NO released from MSCs can also scavenge ROS through the formation of less-toxic reactive nitrogen species (RNS), such as peroxynitrite ${ }^{12,13,47}$. Prolonged ROS exposure during wound-healing induces fibrosis through a mechanism involving membrane lipid oxidation and induction of TGF $\beta 1$ expression ${ }^{87}$.

PGE2 from endothelial cells, fibroblasts and/or myofibroblasts, and cells of the innate immune system, inhibits the release of IL-2 from T cells and dendritic cells, thereby reducing $\mathrm{T}$ cell proliferation at the wound site $^{88}$. PGE2 is also involved in shifting the balance from a T helper $1\left(\mathrm{~T}_{\mathrm{H}} 1\right)$ cell-response into a $\mathrm{T}_{\mathrm{H}} 2$ cell-response by inhibition of IFN $\gamma$ production and upregulation of IL-4 expression, respectively. Low IFN $\gamma$ and high IL-4 levels lead to polarization towards the M2 macrophage phenotype ${ }^{88-90}$. M2 macrophages have a complex role in inflammation, and are generally accepted to be mainly anti-inflammatory, regulate wound healing, suppress $\mathrm{T}$ cell responses and suppress the host defence system ${ }^{91,92}$.

IL-10 is a powerful inhibitor of neutrophil invasion and, therefore, prevents the further release of ROS during inflammation ${ }^{93}$. IL-10 might also reduce the expression of TGF $\beta 1$ and collagens and, additionally, increase the release of MMPs by myofibroblasts ${ }^{93}$. HGF reduces fibrosis through several mechanisms, the most notable of which being the downregulation of TGF $\beta 1$ and collagen production ${ }^{1,4,36}$.

Angiogenesis is an indispensible process during the proliferation phase of wound healing and provides a source of nutrients for the production of ECM components. The absence of adequate angiogenesis leads to deficiencies in wound closure and might lead to the development of a chronic non-healing wound ${ }^{1,4,36}$. Importantly, stem cells release basic fibroblast growth factor (bFGF) and vascular endothelial growth factor A (VEGFA), which provide powerful mitogenic stimuli to promote the proliferation of endothelial cells $s^{12,13,15}$.

Thus, the ability of MSCs to adapt according to their environmental conditions is crucial for understanding their therapeutic potential in fibrotic diseases.

\section{Stem cell therapy for penile fibrosis}

Penile fibrosis, an umbrella term for fibrotic disorders affecting different components of the penis, can be localized either on the tunica albuginea, the corpora cavernosa or the urethral corpus spongiosum (FIG. 2). Owing to a lack of available medical treatment options, 
Normal penis

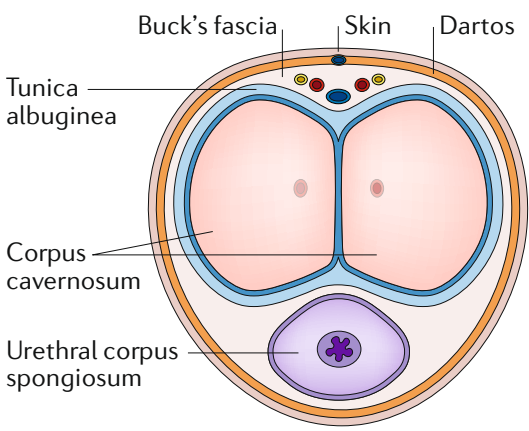

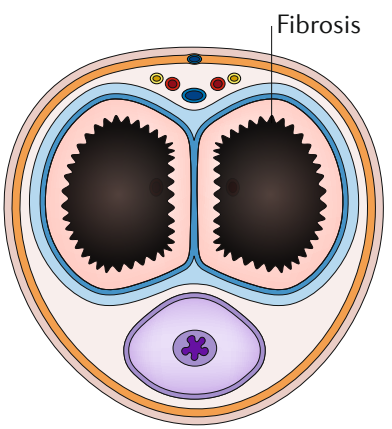

Peyronie's disease

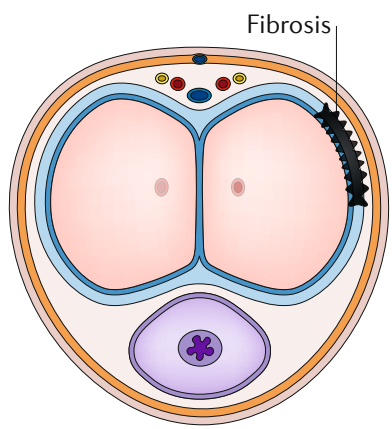

Urethral stricture

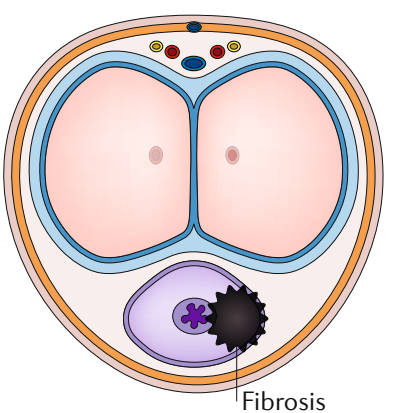

Fig. 2 | Penile fibrosis. Peyronie's disease, urethral stricture and corpora cavernosa fibrosis are fibrotic disorders of the penile connective tissues that are characterized by changes in the collagen composition (formation of a fibrous plaque) of the tunica albuginea, the urethral corpus spongiosum and the penile corpora cavernosa, respectively ${ }^{8,11}$. Corpora cavernosa fibrosis is characterized by a generalized fibrosis in the erectile tissue of the penis. When the expansion of corporal spongy tissue is compromised as a result of fibrosis, rapid filling of the sinusoids will no longer occur, leading to a subsequent lack of compression of the subtunical venules ${ }^{94}$, rendering the penis incapable of becoming completely rigid (corporal veno-occlusive dysfunction). The most important aetiological factors for corpora cavernosa fibrosis include atherosclerosis (owing to chronic penile hypoxia), diabetes mellitus (owing to endothelial dysfunction, nerve damage, impaired arterial flow, reactive oxygen species and advanced glycation end-products (AGEs)), and iatrogenic causes (damage of the neurovascular bundle during prostatectomy in patients with prostate cancer) ${ }^{94-96}$. Peyronie's disease is a localized fibrotic disorder situated on the tunica albuginea of the penis. Peyronie's disease is associated with erectile dysfunction (veno-occlusive dysfunction), curvatures of up to $90^{\circ}$ or more (which impair sexual intercourse) and up to $50 \%$ of patients experience clinically significant depression and/or relationship problems ${ }^{175}$. The leading hypothesis states that Peyronie's disease is caused by repetitive microtrauma as a result of buckling of the penis during intercourse ${ }^{176}$. Patients experience an acute phase with a painful penis (usually during erections), no palpable plaque and a progressive curvature. After 12-24 months, the disease evolves into a chronic, stable plaque and curvature that is painless. Currently available treatment options include surgery and intratunical injections of collagenase in stable disease. Other (medical) treatment options have proven unsuccessful ${ }^{177}$. Urethral strictures are characterized by an abnormal narrowing of the urethra that functionally causes a bladder outlet disorder, which can negatively affect a patient's quality of life by leading to genitourinary infection (epididymitis, prostatitis, cystitis or pyelonephritis), impairing voiding and causing secondary bladder overactivity (with complaints of urgency and urgency incontinence) ${ }^{9}$. Several aetiologies have been proposed and are categorized as iatrogenic, traumatic, inflammatory and idiopathic ${ }^{9}$. Since the advent of endourological surgical techniques and urine catheters, the iatrogenic factors have been the most important causes of urethral strictures.

stem cells - specifically MSCs - have been investigated in both preclinical and clinical studies to inhibit the fibrotic process.

\section{Corpora cavernosa fibrosis}

Historically, the concept of penile fibrosis has almost exclusively been associated with fibrosis of the tunica albuginea and urethral stricture. Conversely, fibrosis of the corpora cavernosa was considered to be a rare condition that was only seen after trauma or following priapism ${ }^{10}$. However, in the past two decades, several studies have shown that corpora cavernosa fibrosis is a common pathological disorder underlying most cases of vasculogenic and/or neurogenic $\mathrm{ED}^{8}$. Penile erection is controlled by a sophisticated mechanism that requires the cooperation of the nitrergic and adrenergic nerves, endothelium and smooth muscle cells of the corpora cavernosa $^{94}$. Diseases and conditions that influence one or more of these elements might cause corporal fibrosis and, therefore, lead to $\mathrm{ED}^{8}$. When the elasticity and compliance of the corporal spongy tissue is reduced (for example, when the corpora cavernosa become fibrotic), filling of the sinusoids with blood will no longer result in the effective engorgement of the corpora cavernosa and will subsequently lead to the insufficient compression of the subtunical venules ${ }^{94}$. This lack of compression will result in leakage of blood from the corporal tissue (corporal veno-occlusive dysfunction; also called 'venous leak') during erection, which renders the penis incapable of becoming completely rigid. ED is caused by several common medical disorders and is defined as the persistent inability to attain and/or maintain an erection that is sufficient for satisfactory sexual performance ${ }^{94}$. For example, diabetes mellitus results in endothelial dysfunction, impaired nitrergic nerve function and the overproduction of ROS and advanced glycation endproducts (AGEs) in the corpora cavernosa ${ }^{95}$. These events, in turn, lead to the reduced bioavailability of $\mathrm{NO}$ and, consequently, impairment of smooth muscle relaxation. In advanced diabetic disease, apoptosis and impaired regeneration of vital cells in the corpora cavernosa, such as endothelial and smooth muscle cells, occurs $^{8}$. The combination of these factors, in addition to chronic relative hypoxia caused by the absence of regular tumescence, render a chronic inflammatory state in the corpora cavernosa and induce the transition of healthy smooth muscle cells into myofibroblasts, which, in combination with infiltrating inflammatory cells, deposit ECM proteins and cause fibrosis ${ }^{96}$. Thus, corporal fibrosis should be considered as a potential cause of treatment failure in ED, particularly because it leads to the sustained impairment of the erectile mechanism, even 


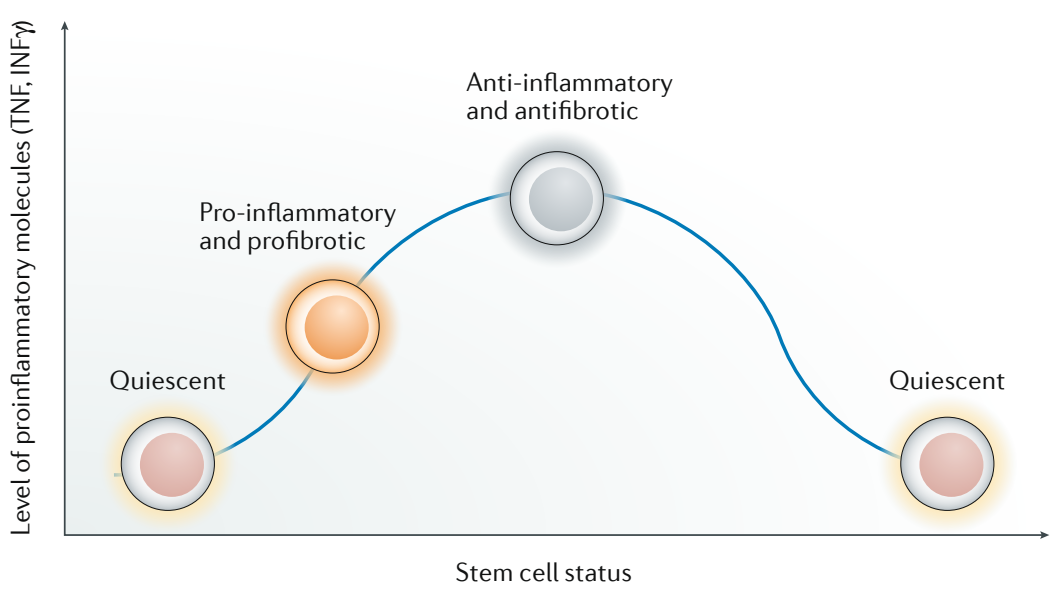

Fig. 3 | Pro-inflammatory and anti-inflammatory MSC phenotypes. Mesenchymal stem cells (MSCs) can both promote and inhibit fibrosis, depending on the inflammatory context in which they function ${ }^{35}$. This paradox is in part explained by their broad immunoregulatory capacities with respect to both the adaptive and innate immune system ${ }^{85}$. By interacting with cells of the innate immune system, MSCs can elicit both anti-inflammatory and pro-inflammatory effects ${ }^{35}$. MSCs are predominantly in a state of quiescence and reduced cellular metabolism ${ }^{47}$. This quiescent state seems to be necessary for the long-term preservation of the reconstituting capacity of stem cells. Stem cells can exit quiescence and rapidly expand and differentiate in response to stress $^{35}$. In the absence of inflammation (low tumour necrosis factor (TNF) and interferon (IFN)- $\gamma$ levels), MSCs can adopt a pro-inflammatory phenotype and enhance M1 macrophage polarization and $\mathrm{T}$ cell response by secreting pro-inflammatory cytokines (IL-1, IL-2, TNF and IFN $\gamma)^{35,85}$. Secretion of TGF $\beta 1$ induces the myofibroblast phenotype, further establishing the inflammatory and profibrotic milieu. In the presence of inflammation (high TNF and IFN $\gamma$ levels), MSCs are activated and adopt an immunosuppressive phenotype ${ }^{35}$. Activated MSCs can also skew the differentiation of monocytes towards an anti-inflammatory and antifibrotic profile, therefore, shifting the balance towards anti-inflammatory M2 macrophage polarization rather than pro-inflammatory M1 macrophage polarization.

Neuropraxia

Temporary loss of motor and/or sensory function in a nerve from the peripheral nervous system as a result of impaired nerve conduction. Neuropraxia usually recovers fully after 6-8 weeks.

Wallerian degeneration Active nerve degeneration resulting from a nerve being cut or crushed, whereby the axonal tail distal to the damage (furthest from the neuronal body) degenerates. when the primary cause has been resolved (for example, after nerve regeneration in iatrogenic neuropraxia of the cavernous nerves) ${ }^{8}$.

Iatrogenic ED, including erectile impairment following the surgical treatment of prostate cancer (radical prostatectomy), is a well-characterized example of the relationship between ED and corpora cavernosa fibrosis. Studies have shown that only $23 \%$ of men aged $<60$ years regain their baseline potency after bilateral nerve-sparing radical prostatectomy (NSRP) ${ }^{97}$. During NSRP surgery, neuropraxia occurs owing to manipulation of the cavernous nerves followed by Wallerian degeneration and loss of conductivity, leading to functional denervation of the smooth muscle in the corpora cavernosa $^{98}$. Similar to noniatrogenic ED, this process results in decreased NO bioavailability and the absence of nocturnal and ergogenic tumescence. The leading hypothesis for this phenomenon states that oxygenated blood is mainly supplied to the penis during erectile activity and, therefore, that the absence of spontaneous tumescence leads to a state of persistent cavernous hypoxia ${ }^{98}$. Both in vitro and in vivo studies support the hypothesis that penile hypoxia results in collagen accumulation, smooth muscle cell apoptosis, and, ultimately, fibrosis ${ }^{96,99-101}$. These changes again seem to be coordinated by TGF $\beta 1$, as multiple studies in rats have illustrated that TGF $\beta 1$ is upregulated at both the gene and protein levels following cavernous nerve crush or transection injury ${ }^{102,103}$. Rho-associated coiledcoil protein kinase (ROCK) isoforms are upregulated and activated in the cavernous tissue following nitrergic denervation, as is the case in many other fibrotic disorders $^{104-106}$. Pharmacological inhibition of ROCK has been shown to ameliorate a variety of fibrotic disorders, which probably occurs through inhibition of myofibroblast proliferation ${ }^{104-106}$. Thus, ROCK upregulation probably has an important role in corpora cavernosa fibrosis. Unsurprisingly, TGF $\beta 1$ is a potential driver of ROCK activation ${ }^{104-106}$.

A final key factor explaining the emergenece of ED after NSRP is the imbalance of the parasympathetic and orthosympathetic nervous system. As a result of neuropraxia of the parasympathetic nerves, an enhanced adrenergic tonus occurs in the corpora cavernosa, which impedes the relaxation of the smooth muscle ${ }^{107}$. Accordingly, long-term administration of $\alpha$-adrenergic antagonists ( $\alpha$-blockers) was shown to improve erections, as well as potentiate the effect of the phosphodiesterase type 5 (PDE5) inhibitor tadalafil in a bilateral cavernous nerve injury (bCNI) rat model and in human corpus cavernosum strips from patients with vasculogenic $\mathrm{ED}^{107}$.

When venous leak occurs, oral medication for ED (PDE5 inhibitors), as well as intracavernosal injections (for example, alprostadil), will have suboptimal or completely absent effects given that the fibrotic penis cannot trap the incoming blood resulting from the pharmacologically induced vasodilation. This observation implies that these patients must resort to penile prosthesis implantation, which is notoriously difficult in the context of fibrotic corporal tissue ${ }^{108}$. Thus, novel therapies that halt the progression of corpora cavernosa fibrosis are urgently needed.

Stem cell therapy for corpora cavernosa fibrosis. In the context of corpora cavernosa fibrosis, the application of stem and progenitor cells from a broad range of sources has been described, including adipose-derived stem cells (ADSCs), bone marrow stem cells (BMSCs), ESCs, endothelial progenitor cells (EPCs), urine-derived stem cells (USCs) and skeletal muscle-derived stem cells (SkMSCs) $^{32,33}$. In the past decade, several studies have evaluated the effect of stem cell therapy on the recovery of erectile function in several animal models of ageing, diabetes mellitus and cavernous nerve injury ${ }^{32,33}$. This Review evaluates select studies that focused on the effect of stem cell therapy on corpora cavernosa fibrosis; studies in which the fibrotic status of the corpora cavernosa was not evaluated (those that only assessed functional erectile function changes) were not considered (TABLE 1). These select studies focused mainly on two aetologies of corpora cavernosa fibrosis using rat models - the diabetic rat model and the bCNI rat model — that mimic ED after radical prostatectomy ${ }^{109-141}$.

In diabetic rat models, BMSCs, USCs and ADSCs have been investigated as treatments for ED (TABLE 1). In studies that evaluated administration of ADSCs and BMSCs, the authors reported contrasting results. One study that used a genetic rat model of diabetes mellitus 
Table 1 | Preclinical studies of stem cell therapy for penile fibrosis

\begin{tabular}{|c|c|c|c|c|c|c|c|c|c|c|}
\hline Study & Species & $\begin{array}{l}\text { Disease } \\
\text { model }\end{array}$ & $\begin{array}{l}\text { Stem cell } \\
\text { type }\end{array}$ & Characterization & $\begin{array}{l}\text { Delivery } \\
\text { and dose }\end{array}$ & $\begin{array}{l}\text { Timing of } \\
\text { treatment }\end{array}$ & $\begin{array}{l}\text { Timing of } \\
\text { evaluation }\end{array}$ & $\begin{array}{l}\text { Method } \\
\text { for fibrosis } \\
\text { evaluation }\end{array}$ & $\begin{array}{l}\text { Effect on } \\
\text { fibrosis }\end{array}$ & Refs \\
\hline \multicolumn{11}{|c|}{ Corpora cavernosa fibrosis } \\
\hline Fang 2018 & SD rat & NSRP-bCNI & $\begin{array}{l}\text { xBMSCs, } \\
\text { xUCBMSCs } \\
\text { (human) }\end{array}$ & 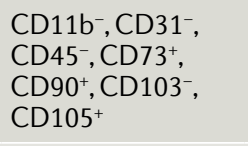 & $\begin{array}{l}\text { Fibrin } \\
\text { scaffold with } \\
\text { SCs }\end{array}$ & $\begin{array}{l}\text { During } \\
\text { bCNI }\end{array}$ & $\begin{array}{l}2 \text { weeks } \\
\text { after } \\
\text { treatment }\end{array}$ & $\begin{array}{l}\text { Histology (MT } \\
\text { and IHC); WB; } \\
\text { qPCR }\end{array}$ & Improved & 146 \\
\hline $\begin{array}{l}\text { Matsuda } \\
2017\end{array}$ & SD rat & NSRP-bCNI & alBMSCs & $\begin{array}{l}\mathrm{CD}^{-} 5^{-}, \mathrm{CD}^{+} 0^{+} \\
\mathrm{CD} \mathrm{C6}^{-}, \mathrm{CD}^{+}\end{array}$ & $\begin{array}{l}\text { i.v. }\left(1 \times 10^{6}\right. \\
\text { cells })\end{array}$ & $\begin{array}{l}\text { i.v. } \\
\text { immediately } \\
\text { after bCNI }\end{array}$ & $\begin{array}{l}\text { After } \\
2 \text { days of } \\
\text { treatment } \\
\text { for qPCR; } \\
\text { after } \\
4 \text { weeks of } \\
\text { treatment } \\
\text { for } \\
\text { histology }\end{array}$ & $\begin{array}{l}\text { Histology (MT } \\
\text { and IHC); qPCR }\end{array}$ & Improved & 143 \\
\hline Wang 2015 & SD rat & $\begin{array}{l}\text { Diabetes } \\
\text { (STZ, } \\
60 \mathrm{mg} / \mathrm{kg})\end{array}$ & $\begin{array}{l}\text { alADSCs } \\
\text { or alADSCs } \\
\text { pretreated } \\
\text { to induce } \\
\text { sub-lethal } \\
\text { hypoxia }\end{array}$ & $\begin{array}{l}\mathrm{CD} 0^{+}, \mathrm{CD}^{2} 9^{+} \text {, } \\
\mathrm{CD}^{-} 5^{-}, \mathrm{CD} 34^{-} ; \\
\text {adipogenic and } \\
\text { osteogenic lineage } \\
\text { differentiation } \\
\text { in vitro }\end{array}$ & $\begin{array}{l}\text { i.c. }\left(1 \times 10^{6}\right. \\
\text { cells })\end{array}$ & $\begin{array}{l}8 \text { weeks } \\
\text { after STZ } \\
\text { injection }\end{array}$ & $\begin{array}{l}4 \text { weeks } \\
\text { after } \\
\text { alADSC } \\
\text { treatment }\end{array}$ & $\begin{array}{l}\text { Histology (MT } \\
\text { and IHC) }\end{array}$ & Improved & 109 \\
\hline Liu 2015 & SD rat & $\begin{array}{l}\text { Diabetes } \\
\text { (STZ, } \\
60 \mathrm{mg} / \mathrm{kg})\end{array}$ & $\begin{array}{l}\text { alADSCs } \\
\text { or alADSCs } \\
\text { expressing } \\
\text { HGF }\end{array}$ & $\begin{array}{l}\mathrm{CD} 0^{+}, \mathrm{CD} 105^{+}, \\
\mathrm{CD} 45^{-}, \mathrm{CD} 13^{-} ; \\
\text {no differentiation } \\
\text { assay }\end{array}$ & $\begin{array}{l}\text { i.c. }\left(2 \times 10^{6}\right. \\
\text { cells })\end{array}$ & $\begin{array}{l}12 \text { weeks } \\
\text { after STZ } \\
\text { injection }\end{array}$ & $\begin{array}{l}4 \text { weeks } \\
\text { after } \\
\text { alADSC } \\
\text { treatment }\end{array}$ & $\begin{array}{l}\text { Histology (MT } \\
\text { and IHC) }\end{array}$ & Improved & 110 \\
\hline Ryu 2016 & $\begin{array}{l}\mathrm{C} 57 \\
\text { BL/6 J } \\
\text { mice }\end{array}$ & $\begin{array}{l}\text { Diabetes } \\
\text { (STZ, } \\
50 \mathrm{mg} / \mathrm{kg} \text { ) }\end{array}$ & alBMSCs & $\begin{array}{l}\mathrm{CD} 44^{+}, \mathrm{SCA} 1^{+}, \\
\mathrm{CD}^{-} 4^{-}, \mathrm{CD} 45^{-}, \\
\text {MHC I-; } \\
\text { adipogenic, } \\
\text { chondrogenic and } \\
\text { osteogenic lineage } \\
\text { differ-entiation } \\
\text { in vitro }\end{array}$ & $\begin{array}{l}\text { i.c. }\left(3 \times 10^{6}\right. \\
\text { cells) }\end{array}$ & $\begin{array}{l}8 \text { weeks } \\
\text { after STZ } \\
\text { injection }\end{array}$ & $\begin{array}{l}2 \text { weeks } \\
\text { after } \\
\text { alBMSC } \\
\text { treatment }\end{array}$ & $\begin{array}{l}\text { Histology (MT } \\
\text { and IHC) }\end{array}$ & Improved & 119 \\
\hline $\begin{array}{l}\text { Ouyang } \\
2014\end{array}$ & SD rat & $\begin{array}{l}\text { Diabetes } \\
\text { (STZ, } \\
35 \mathrm{mg} / \mathrm{kg} \\
\text { plus high- } \\
\text { fat diet for } \\
4 \text { weeks) }\end{array}$ & $\begin{array}{l}\text { xUSCs } \\
\text { (human) } \\
\text { or xUSCs } \\
\text { (human) } \\
\text { expressing } \\
\text { FGF2 }\end{array}$ & $\begin{array}{l}\text { CD24 }^{+}(100 \%), \\
\text { CD29 }^{+}(99.9 \%), \\
\text { CD44 }^{+}(98.7 \%), \\
\text { CD73 }^{+}(98.6 \%), \\
\text { CD }^{+}(99.9 \%), \\
\text { CD146 }^{+}(99.3 \%), \\
\text { SSEA-4 }^{+}(98.4 \%), \\
\text { CD105 } \\
\text { STRO- }(8.06 \%), \\
\text { CD }^{+}(14.03 \%) \text {, } \\
\text { CD3.1\%), } \\
\text { CD45 }(2.75 \%), \\
\text { no differentiation } \\
\text { assay }\end{array}$ & $\begin{array}{l}\text { i.c. }\left(1 \times 10^{6}\right. \\
\text { cells })\end{array}$ & $\begin{array}{l}8 \text { weeks } \\
\text { after STZ } \\
\text { injection }\end{array}$ & $\begin{array}{l}4 \text { weeks } \\
\text { after } x U S C \\
\text { treatment }\end{array}$ & $\begin{array}{l}\text { Histology (MT } \\
\text { and IHC) }\end{array}$ & Improved & 132 \\
\hline
\end{tabular}


Table 1 (cont.) | Preclinical studies of stem cell therapy for penile fibrosis

\begin{tabular}{|c|c|c|c|c|c|c|c|c|c|c|}
\hline Study & Species & $\begin{array}{l}\text { Disease } \\
\text { model }\end{array}$ & $\begin{array}{l}\text { Stem cell } \\
\text { type }\end{array}$ & Characterization & $\begin{array}{l}\text { Delivery } \\
\text { and dose }\end{array}$ & $\begin{array}{l}\text { Timing of } \\
\text { treatment }\end{array}$ & $\begin{array}{l}\text { Timing of } \\
\text { evaluation }\end{array}$ & $\begin{array}{l}\text { Method } \\
\text { for fibrosis } \\
\text { evaluation }\end{array}$ & $\begin{array}{l}\text { Effect on } \\
\text { fibrosis }\end{array}$ & Refs \\
\hline \multicolumn{11}{|c|}{ Corpora cavernosa fibrosis (cont.) } \\
\hline Wang 2017 & SD rat & $\begin{array}{l}\text { Diabetes } \\
\text { (STZ, } \\
60 \mathrm{mg} / \mathrm{kg})\end{array}$ & alADSCs & $\begin{array}{l}\mathrm{CD}^{+} 0^{+}, \mathrm{CD} 29^{+} \text {, } \\
\mathrm{CD} 45^{-}, \mathrm{CD} 34^{-} ; \\
\text {adipogenic and } \\
\text { osteogenic } \\
\text { lineage } \\
\text { differentiation } \\
\text { in vitro }\end{array}$ & $\begin{array}{l}\text { i.c. }\left(1 \times 10^{6}\right. \\
\text { cells })\end{array}$ & $\begin{array}{l}\text { Not } \\
\text { reported }\end{array}$ & $\begin{array}{l}4 \text { weeks } \\
\text { after } \\
\text { alADSC } \\
\text { injection }\end{array}$ & Histology (MT) & Improved & 138 \\
\hline $\begin{array}{l}\text { Kovanecz } \\
2016\end{array}$ & ZDF rats & $\begin{array}{l}\text { Diabetes } \\
\text { (genetic) }\end{array}$ & alMDSCs & Not reported & $\begin{array}{l}\text { i.c. }\left(1 \times 10^{6}\right. \\
\text { cells })\end{array}$ & $\begin{array}{l}\text { Not } \\
\text { reported }\end{array}$ & $\begin{array}{l}8 \text { weeks } \\
\text { after } \\
\text { alMDSC } \\
\text { injection }\end{array}$ & $\begin{array}{l}\text { Histology (MT); } \\
\text { hydroxyproline } \\
\text { assay }\end{array}$ & Improved & 138 \\
\hline Garcia 2010 & ZDF rats & $\begin{array}{l}\text { Diabetes } \\
\text { (genetic) }\end{array}$ & alADSCs & Not reported & $\begin{array}{l}\text { i.c. }\left(1 \times 10^{6}\right. \\
\text { cells })\end{array}$ & $\begin{array}{l}\text { Not } \\
\text { reported }\end{array}$ & $\begin{array}{l}5 \text { weeks } \\
\text { after } \\
\text { alADSC } \\
\text { injection }\end{array}$ & Histology (MT) & Worsened & 141 \\
\hline $\begin{array}{l}\text { Huang } \\
2016\end{array}$ & SD rat & $\begin{array}{l}\text { Tobacco- } \\
\text { associated- } \\
\text { ED ( } 2 \text { hours } \\
\text { of } \\
\text { continuous } \\
\text { cigarette } \\
\text { smoke } \\
\text { exposure } \\
\text { per day, } 5 \\
\text { days per } \\
\text { week for } \\
12 \text { weeks) }\end{array}$ & aADSCs & Not reported & $\begin{array}{l}\text { i.c. }\left(1 \times 10^{6}\right. \\
\text { cells })\end{array}$ & $\begin{array}{l}12 \text { weeks } \\
\text { after } \\
\text { tobacco } \\
\text { exposure }\end{array}$ & $\begin{array}{l}4 \text { weeks } \\
\text { after } \\
\text { aADSC } \\
\text { treatment }\end{array}$ & Histology (MT) & Improved & 111 \\
\hline $\begin{array}{l}\text { Kovanecez } \\
2012\end{array}$ & $\begin{array}{l}\text { Fisher } \\
\text { rat }\end{array}$ & bCNR & $\begin{array}{l}\text { xMDSCs } \\
\text { (mouse) }\end{array}$ & $\begin{array}{l}\mathrm{SCA} 1^{+}, \mathrm{CD} 34^{+} \text {, } \\
\mathrm{CD} 44^{+} ; \text {no } \\
\text { differentiation } \\
\text { assay }\end{array}$ & $\begin{array}{l}\text { i.c. }\left(1 \times 10^{6}\right. \\
\text { cells })\end{array}$ & $\begin{array}{l}\text { Immediately } \\
\text { after bCNR }\end{array}$ & $\begin{array}{l}6 \text { weeks } \\
\text { after } \\
\text { xMDSC } \\
\text { treatment }\end{array}$ & Histology (MT) & Improved & 112 \\
\hline Ying 2014 & SD rat & bCNR & alADSCs & Not reported & $\begin{array}{l}\text { i.v. }\left(2 \times 10^{6}\right. \\
\text { cells) plus } \\
\text { microsurgical } \\
\text { repair of the } \\
\text { resected } \\
\text { CN by } \\
\text { autologous } \\
\text { saphenous } \\
\text { vein graft }\end{array}$ & $\begin{array}{l}\text { Immediately } \\
\text { after bCNR }\end{array}$ & $\begin{array}{l}12 \text { weeks } \\
\text { after } \\
\text { alADSC } \\
\text { treatment }\end{array}$ & Histology (MT) & Improved & 113 \\
\hline Chen 2016 & SD rat & $\mathrm{bCNI}$ & alADSCs & $\begin{array}{l}\text { CD73 }^{+}(99.2 \%), \\
\text { CD90 }^{+}(94.5 \%), \\
\text { CD105 }^{+}(58.6 \%), \\
\text { CD146 }^{-}(1.87 \%), \\
\text { CD31- }(1.55 \%), \\
\text { CD34- }(1.92 \%), \\
\text { CD45- }(1.31) \text {, } \\
\text { CD117- }(1.28) ; \\
\text { adipogenic and } \\
\text { osteogenic } \\
\text { lineage } \\
\text { differentiation } \\
\text { in vitro }\end{array}$ & $\begin{array}{l}\text { i.c. }\left(1 \times 10^{6}\right. \\
\text { cells) }\end{array}$ & $\begin{array}{l}\text { Immediately } \\
\text { after bCNI }\end{array}$ & $\begin{array}{l}4 \text { weeks } \\
\text { after } \\
\text { alADSC } \\
\text { treatment }\end{array}$ & Histology (MT) & Improved & 114 \\
\hline
\end{tabular}


Table 1 (cont.) | Preclinical studies of stem cell therapy for penile fibrosis

\begin{tabular}{|c|c|c|c|c|c|c|c|c|c|c|}
\hline Study & Species & $\begin{array}{l}\text { Disease } \\
\text { model }\end{array}$ & $\begin{array}{l}\text { Stem cell } \\
\text { type }\end{array}$ & Characterization & $\begin{array}{l}\text { Delivery } \\
\text { and dose }\end{array}$ & $\begin{array}{l}\text { Timing of } \\
\text { treatment }\end{array}$ & $\begin{array}{l}\text { Timing of } \\
\text { evaluation }\end{array}$ & $\begin{array}{l}\text { Method } \\
\text { for fibrosis } \\
\text { evaluation }\end{array}$ & $\begin{array}{l}\text { Effect on } \\
\text { fibrosis }\end{array}$ & Refs \\
\hline \multicolumn{11}{|c|}{ Corpora cavernosa fibrosis (cont.) } \\
\hline You 2015 & SD rat & $\mathrm{bCNI}$ & $\begin{array}{l}\text { alADSCs or } \\
\text { aSVF }\end{array}$ & $\begin{array}{l}\text { - aSVF: CD45 } 5^{+} \\
\text {(33\%), CD452/ } \\
\text { CD31 }(6 \%) ; 57 \% \\
\text { of cells expressed } \\
\text { neither CD45 } \\
\text { nor CD31; CD73 } \\
\text { and CD90 were } \\
\text { expressed by } \\
\text { almost two- } \\
\text { fifths of CD452+ } \\
\text { cells. } \\
\text { alADSCs: } \\
\text { CD29+ }(99.8 \%), \\
\text { CD44 }(99.9 \%), \\
\text { CD73 }(99.9 \%), \\
\text { CD90 }(99.9 \%), \\
\text { CD34- }(0.2) \%, \\
\text { CD45- }(0.1 \%) ; \text { no } \\
\text { differentiation } \\
\text { assay }\end{array}$ & $\begin{array}{l}\text { i.c. }\left(1 \times 10^{6}\right. \\
\text { cells) }\end{array}$ & $\begin{array}{l}\text { Immediately } \\
\text { after bCNI }\end{array}$ & $\begin{array}{l}4 \text { weeks } \\
\text { after } \\
\text { treatment }\end{array}$ & Histology (MT) & Improved & 117 \\
\hline Ryu 2014 & $\begin{array}{l}\text { C57 } \\
\text { BL/6 J } \\
\text { mice }\end{array}$ & $\mathrm{bCNI}$ & alBMSCs & $\begin{array}{l}\mathrm{CD} 44^{+}, \mathrm{SCA} 1^{+} \\
\mathrm{CD} 34^{-}, \mathrm{CD} 45^{-} \text {, } \\
\mathrm{MHC} \mathrm{II}^{-} ; \text {no } \\
\text { differentiation } \\
\text { assay }\end{array}$ & $\begin{array}{l}\text { i.c. or i.p. } \\
\left(5 \times 10^{5} \text { cells }\right)\end{array}$ & $\begin{array}{l}\text { Immediately } \\
\text { after bCNI }\end{array}$ & $\begin{array}{l}2 \text { weeks } \\
\text { after } \\
\text { alBMSC } \\
\text { treatment }\end{array}$ & Histology (MT) & Improved & 121 \\
\hline Qui 2012 & SD rat & $\mathrm{bCNI}$ & aSVF & Not reported & $\begin{array}{l}\text { i.c. of } 400 \mathrm{ml} \\
\text { SVF solution } \\
(5000 \text { cells } \\
\text { per } \mu \mathrm{L})\end{array}$ & $\begin{array}{l}\text { The same } \\
\text { day or } \\
4 \text { weeks } \\
\text { after bCNI }\end{array}$ & $\begin{array}{l}2 \text { weeks } \\
\text { after aSVF } \\
\text { treatment }\end{array}$ & Histology (MT) & Improved & 120 \\
\hline Jeong 2013 & SD rat & $\mathrm{bCNI}$ & $\begin{array}{l}\text { xADSCs } \\
\text { (human) } \\
\text { covered } \\
\text { with a } \\
\text { BDNF- } \\
\text { PLGA } \\
\text { membrane }\end{array}$ & Not reported & $\begin{array}{l}\text { Periprostatic } \\
\text { implantation } \\
\left(1 \times 10^{6} \text { cells }\right)\end{array}$ & $\begin{array}{l}\text { Immediately } \\
\text { after bCNI }\end{array}$ & $\begin{array}{l}4 \text { weeks } \\
\text { after } \\
\text { xADSC } \\
\text { treatment }\end{array}$ & Histology (MT) & Improved & 122 \\
\hline $\begin{array}{l}\text { Fandel } \\
2012\end{array}$ & SD rat & $\mathrm{bCNI}$ & alADSCs & Not reported & $\begin{array}{l}\text { i.c. }\left(2 \times 10^{6}\right. \\
\text { cells })\end{array}$ & $\begin{array}{l}\text { Immediately } \\
\text { after bCNI }\end{array}$ & $\begin{array}{l}4 \text { weeks } \\
\text { after } \\
\text { alADSC } \\
\text { treatment }\end{array}$ & Histology (MT) & Improved & 123 \\
\hline Ying 2013 & SD rat & $\mathrm{bCNI}$ & aADSCs & Not reported & $\begin{array}{l}\text { i.c. }\left(1 \times 10^{6}\right. \\
\text { cells })\end{array}$ & $\begin{array}{l}\text { Immediately } \\
\text { after bCNI }\end{array}$ & $\begin{array}{l}4 \text { weeks } \\
\text { after } \\
\text { aADSC } \\
\text { treatment }\end{array}$ & Histology (MT) & Improved & 124 \\
\hline
\end{tabular}


Table 1 (cont.) | Preclinical studies of stem cell therapy for penile fibrosis

\begin{tabular}{|c|c|c|c|c|c|c|c|c|c|c|}
\hline Study & Species & $\begin{array}{l}\text { Disease } \\
\text { model }\end{array}$ & $\begin{array}{l}\text { Stem cell } \\
\text { type }\end{array}$ & Characterization & $\begin{array}{l}\text { Delivery } \\
\text { and dose }\end{array}$ & $\begin{array}{l}\text { Timing of } \\
\text { treatment }\end{array}$ & $\begin{array}{l}\text { Timing of } \\
\text { evaluation }\end{array}$ & $\begin{array}{l}\text { Method } \\
\text { for fibrosis } \\
\text { evaluation }\end{array}$ & $\begin{array}{l}\text { Effect on } \\
\text { fibrosis }\end{array}$ & Refs \\
\hline \multicolumn{11}{|c|}{ Corpora cavernosa fibrosis (cont.) } \\
\hline Zhu 2015 & SD rat & $\mathrm{bCNI}$ & $\begin{array}{l}\text { xUCBMSCs } \\
\text { (human) }\end{array}$ & $\begin{array}{l}\mathrm{CD}^{2} 9^{+}(99.95 \%), \\
\mathrm{CD}_{4}{ }^{+}(97.2 \%), \\
\mathrm{CD} 105^{+}(90 \%), \\
\mathrm{CD}^{-}(0.05 \%), \\
\text { CD34- }(0.73 \%) ; \text { no } \\
\text { differentiation assay }\end{array}$ & $\begin{array}{l}\text { i.c. }\left(2 \times 10^{6}\right. \\
\text { cells })\end{array}$ & $\begin{array}{l}\text { Immediately } \\
\text { after bCNI }\end{array}$ & $\begin{array}{l}4 \text { weeks } \\
\text { after } \\
\text { xUCBMSC } \\
\text { treatment }\end{array}$ & Histology (MT) & Improved & 127 \\
\hline Song 2016 & SD rat & $\mathrm{bCNI}$ & $\begin{array}{l}\text { xUCBMSCs } \\
\text { (human) or } \\
\text { xUCBMSCs } \\
\text { (human) } \\
\text { expressing } \\
\text { BDNF }\end{array}$ & Not reported & $\begin{array}{l}\text { i.c. }\left(2 \times 10^{6}\right. \\
\text { cells })\end{array}$ & $\begin{array}{l}\text { Immediately } \\
\text { after bCNI }\end{array}$ & $\begin{array}{l}4 \text { weeks } \\
\text { after } \\
\text { xUCBMSC } \\
\text { treatment }\end{array}$ & Histology (MT) & Improved & 128 \\
\hline \multicolumn{11}{|c|}{ Tunica albuginea fibrosis (Peyronie's disease) } \\
\hline $\begin{array}{l}\text { Goktce } \\
2014\end{array}$ & SD rat & $\begin{array}{l}\text { PD } \\
\text { (TGF } \beta 1 \mathrm{TA} \\
\text { injection) }\end{array}$ & alADSCs & 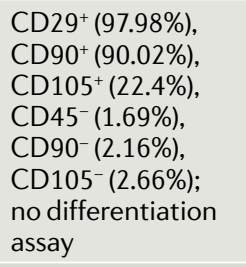 & $\begin{array}{l}\text { TA injection } \\
\left(5 \times 10^{5} \text { cells }\right)\end{array}$ & $\begin{array}{l}\text { The same } \\
\text { day or } 30 \\
\text { days after } \\
\text { the TGF } \beta 1 \\
\text { injection }\end{array}$ & $\begin{array}{l}5 \text { weeks } \\
\text { after } \\
\text { alADSC } \\
\text { treatment }\end{array}$ & Histology (MT) & Improved & 129 \\
\hline $\begin{array}{l}\text { Goktce } \\
2015\end{array}$ & SD rat & $\begin{array}{l}\text { PD } \\
\text { (TGF } \beta 1 \text { TA } \\
\text { injection) }\end{array}$ & $\begin{array}{l}\text { alADSCs } \\
\text { or alADSCs } \\
\text { expressing } \\
\text { IFNa2b }\end{array}$ & 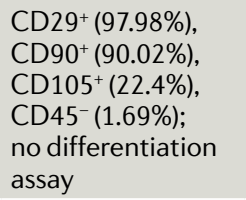 & $\begin{array}{l}\text { TA injection } \\
\left(5 \times 10^{5} \text { cells }\right)\end{array}$ & $\begin{array}{l}\text { The same } \\
\text { day or } \\
4 \text { weeks } \\
\text { after TGF } \beta 1 \\
\text { injection }\end{array}$ & $\begin{array}{l}5 \text { weeks } \\
\text { after } \\
\text { alADSC } \\
\text { treatment }\end{array}$ & $\begin{array}{l}\text { Histology (MT } \\
\text { and VVG) }\end{array}$ & Improved & 130 \\
\hline $\begin{array}{l}\text { Castiglione } \\
2013\end{array}$ & SD rat & $\begin{array}{l}\text { PD } \\
\text { (TGF } \beta 1 \text { TA } \\
\text { injection) }\end{array}$ & $\begin{array}{l}\text { xADSCs } \\
\text { (human) }\end{array}$ & 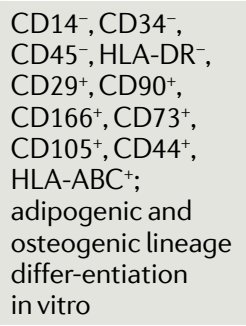 & $\begin{array}{l}\text { TA injection } \\
\left(1 \times 10^{6} \text { cells }\right)\end{array}$ & $\begin{array}{l}\text { The day } \\
\text { after TGF } \beta 1 \\
\text { injection }\end{array}$ & $\begin{array}{l}5 \text { weeks } \\
\text { after } \\
\text { xADSC } \\
\text { treatment }\end{array}$ & $\begin{array}{l}\text { Histology }(\mathrm{IHC}) \text {; } \\
\text { WB }\end{array}$ & Improved & 131 \\
\hline
\end{tabular}


Table 1 (cont.) | Preclinical studies of stem cell therapy for penile fibrosis

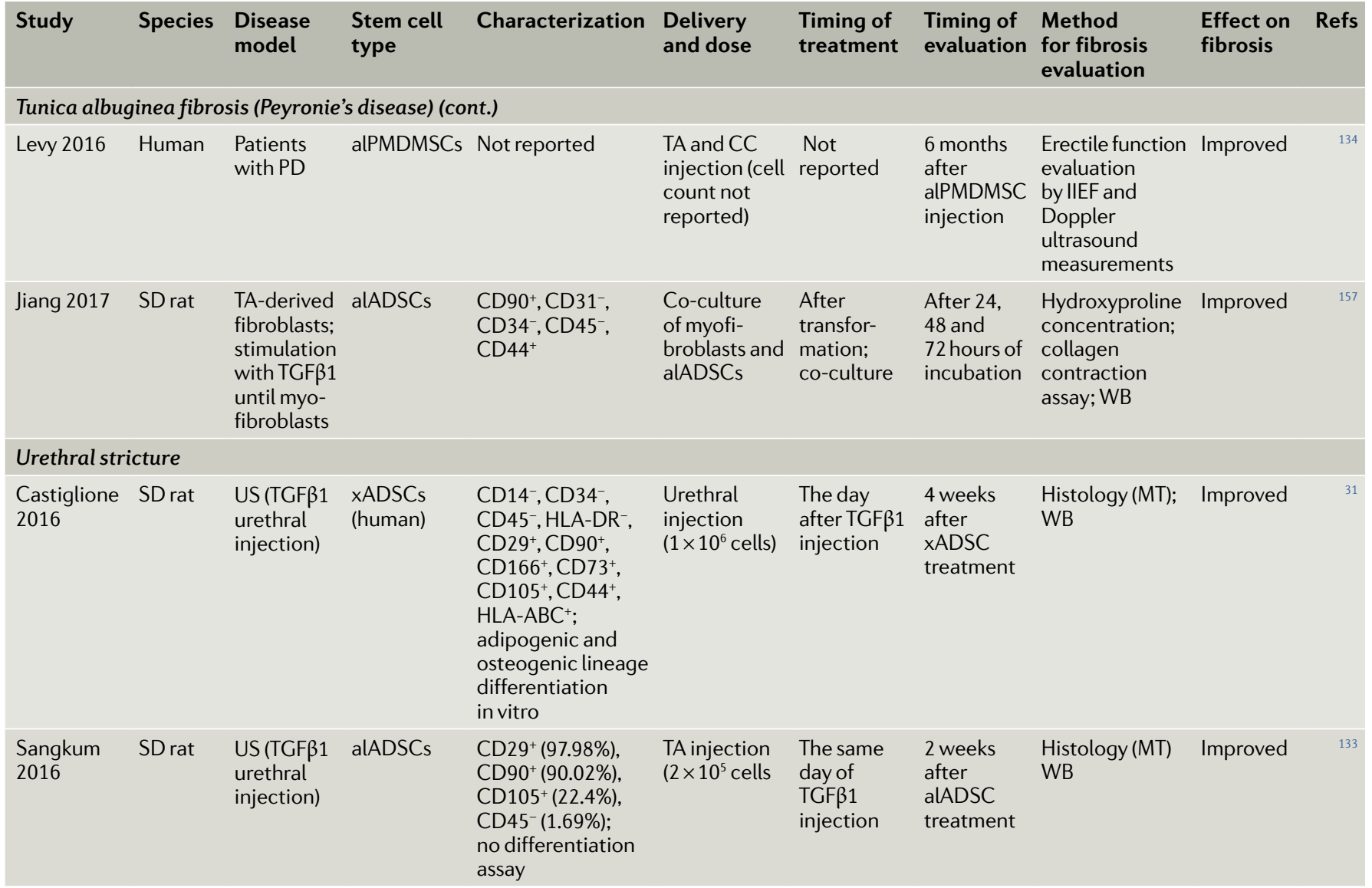

aADSCs, autologous adipose-derived stem cells; alADSCs, allogeneic adipose-derived stem cells; alBMSCs, allogeneic bone marrow-derived stem cells; alMDSCs, allogeneic muscle-derived stem cells; alPMDMSCs, allogeneic placental matrix-derived mesenchymal stem cells; aSVF, autologous stromal vascular fraction; bCNI, bilateral cavernous nerve crush injury; bCNR, bilateral cavernous nerve resection; BDNF, brain-derived neurotrophic factor; CC, corpora cavernosa; CN, cavernous nerve; ED, erectile dysfunction; FGF2, fibroblast growth factor 2; HGF, hepatocyte growth factor; HLA-ABC, MHC class I antigen; HLA-DR, human leukocyte antigen DR isotype; i.c., intracavernosal injection; IFNa2b, interferon- $\alpha 2 \mathrm{~b}$; IHC, immunohistochemistry; IIEF, International Index of Erectile Function; i.p., intraperitoneal injection; i.v., intravenous injection; MHC II, class II major histocompatibility complex; MT, Masson's trichrome; NGF, nerve growth factor; NSRP, nerve-sparing radical prostatectomy; PD, Peyronie's disease; PLGA, poly-lactic-co-glycolic; qPCR, quantitative PCR; SCA1, ataxin-1; SD, Sprague-Dawley; SSEA-4, stage-specific embryonic antigen-4; STZ, streptozotocin; TA, tunica albuginea; TGF $\beta 1$, transforming growth factor- $\beta 1$; US, urethral stricture; VEGF, vascular endothelial growth factor; VVG, Verhoeff-van Gieson; WB, western blot; WK, Wistar Kyoto; xADSCs, xenogeneic adipose-derived stem cells; xBMSCs, xenogeneic bone marrow-derived stem cells; xMDSC, xenogeneic muscle-derived stem cells; xUCBMSCs, xenogeneic umbilical cord blood mesenchymal stem cells; $x U S C s$, xenogeneic urine-derived stem cells; xUSCs-PEDF, xenogeneic urine-derived stem cells genetically modified with pigment epithelium-derived factor; ZDF, Zucker diabetic fatty.

reported that the ratio of intracavernosal collagen to smooth muscle was not significantly different between autologous ADSC treatment and control groups ${ }^{141}$. However, an increase in corpora cavernosa innervation and endothelial cell number was observed in the treatment group. Conversely, another study reported that allogeneic ADSC treatment enhanced the recovery of the smooth muscle and reduced fibrosis in corpus cavernosum of a streptozotocin-induced model of diabetes mellitus in rats ${ }^{109}$. Two studies found that the injection of BMSCs markedly decreased cavernous fibrosis and improved smooth muscle content in mice with chemically-induced diabetes after only 2 weeks ${ }^{119,137}$. In addition, these studies confirmed the improvements in nitrergic innervation and endothelial cell content with stem cell therapy.

Other studies have modified the stem cells before injection to increase their efficacy. The ability of allogeneic ADSCs modified to express VEGF - a signalling protein normally produced by endothelial and inflammatory cells that stimulates angiogenesis and has possible immunomodulatory effects - to reverse diabetic ED in rats was evaluated in one study ${ }^{139}$. This study reported an increase in the intracavernosal smooth muscle:collagen ratio and endothelial nitric oxide synthase (eNOS) expression in the group treated with $V E G F$-transfected ADSCs compared with those that received unmodified ADSCs. Another group evaluated the efficacy of ADSCs expressing HGF in a diabetic rat model $^{110}$; ADSCs improved erectile function and decreased fibrosis (increased content of smooth muscle, improved smooth muscle:collagen ratio and lower apoptotic index), but HGF-transfected ADSC had superior effects with respect to almost all parameters. Additionally, HGF-transfected ADSCs increased platelet and endothelial cell adhesion molecule 1 (PECAM1) and eNOS expression levels, further suggesting attenuated fibrosis.

Fibroblast growth factor 2 (FGF2) has an important role in the regulation of cell survival, cell division, 
angiogenesis, differentiation and cell migration ${ }^{142}$. In a diabetic rat model of ED and penile fibrosis, intracavernous injection of human USCs transfected with FGF2 markedly improved the intracavernosal smooth muscle:collagen ratio and increased the expression of VEGF and eNOS compared with other treatments (vehicle, USC only and FGF2 delivered to the tissue via lentivirus $)^{132}$.

Several studies have evaluated the effect of stem cell therapy in rat models of radical prostatectomy (modelled by severing the cavernous nerves, either by crushing or transection). The first use of allogeneic ADSCs in the bCNI rat model was reported in 2010 (REF. ${ }^{115}$ ). In this study, erectile function was improved at 4 weeks after allogeneic ADSC injection. Moreover, smooth muscle content was partially restored, corpora cavernosa fibrosis was prevented and neuronal nitric oxide synthase (nNOS; encoded by Nos1) expression was restored in the dorsal penile nerves. The findings of many other studies that used similar methodologies support these results and confirmed that prevention of corpora cavernosa fibrosis in the bCNI rat model was possible through intracavernous injection of ADSCs ${ }^{113,114,123,124}$. Furthermore, these studies investigated whether injected ADSCs remained at the site of injection (suggesting engraftment) or whether they were transported elsewhere. Surprisingly, they found that ADSCs dispersed to a niche resembling their usual site (for example, the perivascular space of the bone marrow) or the major pelvic ganglion (MPG). Two studies also reported that periprostatic application of human ADSCs incorporated in hydrogels and/or membranes containing neurotrophic factors prevented corpora cavernosa fibrosis and increased eNOS protein expression after 4 weeks in a bCNI rat model ${ }^{116,122}$.

Intravenous infusion of green fluorescent protein (GFP)-labelled allogeneic BMSCs was also effective in preventing corpora cavernosa fibrosis in a bCNI rat model $^{143}$. Interestingly, following infusion, BMSC homing to the MPGs and injured cavernous nerves was observed. Additionally, higher mRNA expression of brain-derived neurotrophic factor $(B d n f)$ and glial cell line-derived neurotrophic factor $(G d n f)$ was seen in the MPGs of BMSC-treated rats compared to untreated rats, indicative of improved neuronal repair mechanisms.

Allogeneic ADSCs have been shown to secrete greater levels of bFGF, insulin-like growth factor (IGF) and VEGF than resident corporal cells, and allogeneic ADSC treatment was shown to increase the concentration of these molecules in the penile tissues of aged rats, which had the beneficial effect of lowering oxidative stress $^{144}$. Allogeneic ADSCs also increased the endothelial and cavernous smooth muscle content in the corpora cavernosa, which led to improved erectile function.

Stromal vascular fraction (SVF) is a component of the lipoaspirate obtained from liposuction of excess adipose tissue, which contains a large population of $\mathrm{ADSCs}^{145}$. In two studies that used the same animal model of NSRP ${ }^{117,120}$, SVF treatment - either immediately after or 4 weeks after CNI injury - markedly prevented and reduced corpora cavernosa fibrosis and increased the expression of nNOS and neurofilament in the dorsal penile nerves, even in comparison with allogeneic ADSC injection.

The most commonly used stem cells in basic research have been ADSCs, but a few studies have evaluated the effect of xenogeneic BMSCs and human umbilical cord blood MSCs (UCBMSCs) (TABLE 1). BMSCs were equally efficient as daily administration of tadalafil in preventing fibrosis in a bCNI rat model ${ }^{118}$. Both intracavernosal and intraperitoneal injections of BMSCs markedly restored endothelial and smooth muscle content in the corpora cavernosa, as well as penile levels of nNOS and neurofilament ${ }^{121}$.

An additive effect of using a fibrin scaffold containing xenogeneic BMSCs and UCBMSCs in rats during bCNI surgery was observed with respect to improved erectile function, increased nNOS and PECAM1 mRNA expression and decreased mRNA expression of $a$-actin expression and caspase 3 (REF. ${ }^{146}$ ); histological assessment and immunostaining corroborated these results.

Overall, a large amount of preclinical data suggests the benefit of stem cells (predominantly ADSCs) as an antifibrotic treatment strategy for corpora cavernosa fibrosis. However, further characterisation of the route of administration, timing and the molecular effectors of stem cells will be required to translate these findings into the clinical setting.

\section{Peyronie's disease}

Peyronie's disease is a chronic fibrotic disease of the penile shaft, the course of which occurs over 12-24 months and is divided into the acute (exacerbating curvature; painful) and chronic (stabilization of deformation; painless) phases ${ }^{11}$. Peyronie's disease is commonly believed to occur as a result of repetitive trauma and buckling of the tunica albuginea during intercourse ${ }^{96}$. Two leading theories concerning the onset of Peyronie's disease are commonly referred to in the scientific literature ${ }^{6,96,147}$. The first theory suggests that trauma separates the inner and outer layer of tunica albuginea, preferentially at the dorsomedial aspect of the penis where the inner layer forms the intercavernous septum. The second hypothesis suggests that trauma separates the sinusoidal tissue from the inner layer of the tunica albuginea, causing haematoma formation in the space of Smith. The first hypothesis is evidenced by the fact that Peyronie's disease most often occurs at the dorsomedial aspect of the penis, whereas the most convincing argument for the second theory is the finding that fibrotic plaques in Peyronie's disease frequently extend into the corpus cavernosum and are not limited to the tunica albuginea.

Independent of the exact pathophysiological mechanism, these virtual spaces (either between the inner and outer layer of the tunica albuginea or between the inner layer and the space of Smith) represent planes in which endothelial damage can occur resulting from rupture of the small vessels during trauma or friction. The role of trauma in the pathophysiology of Peyronie's disease is supported by findings from studies in various rat models, in which injection of TGF $\beta 1$, surgical trauma and suturing of the rat tunica albuginea caused an increase in the thickness of the tunica albuginea and fragmentation of the elastic fibres of the tunical tissue ${ }^{148-150}$. 


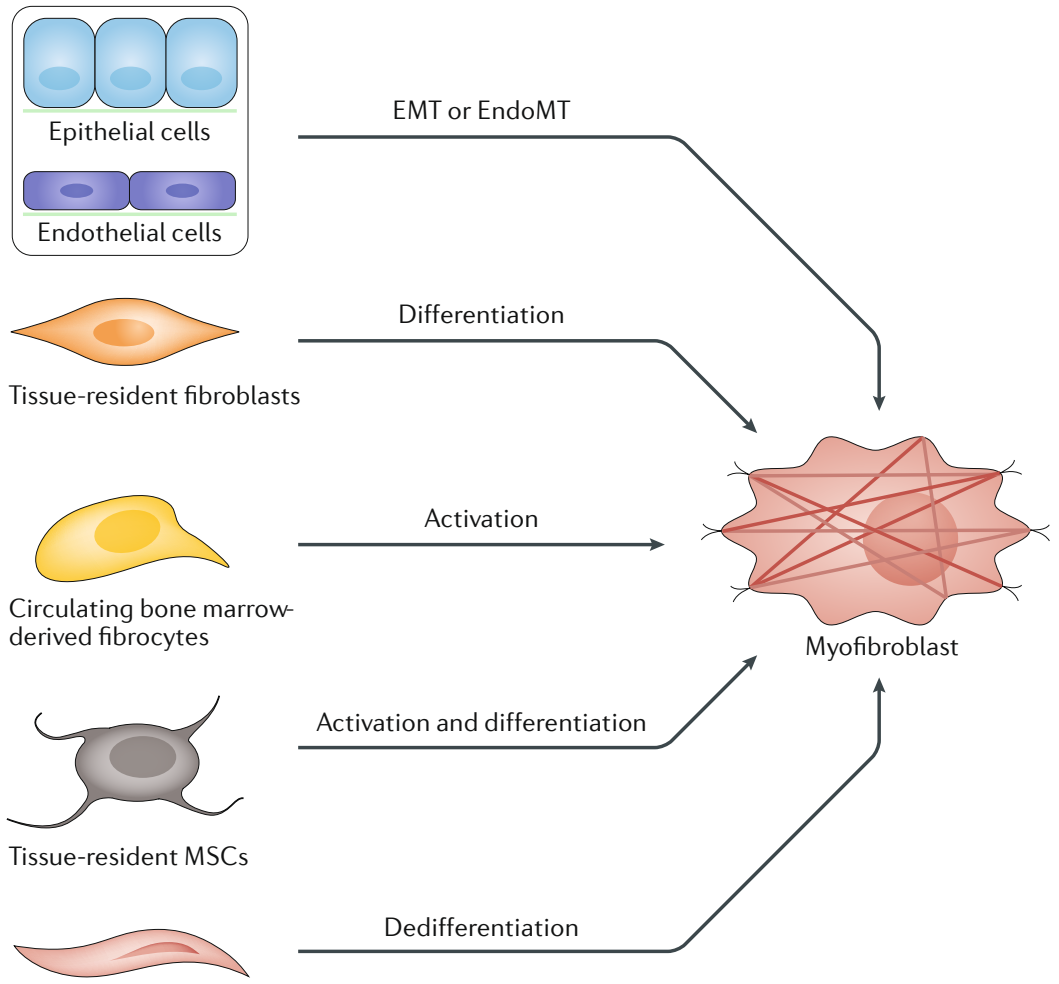

Smooth muscle cells

Fig. 4 | The origin of myofibroblasts. Myofibroblasts are possibly the most unique cells involved in the wound-healing process; they actively regulate the extracellular matrix (ECM) while simultaneously possessing a cytoskeletal contractile apparatus similar to that of smooth muscle cells ${ }^{178,179}$. Local cells undergo a phenotypic switch into myofibroblasts, which is indicated by the production of the myofibroblast marker $\alpha$-smooth muscle actin ( $\alpha \mathrm{SMA}$ ) and ECM components such as collagens (mostly type I and III collagen), laminin and fibronectin, a process that is mainly driven by transforming growth factor- $\beta 1$ (TGF $\beta 1)^{170-172}$. The principal myofibroblast progenitor after the tissue injury seems to vary, and includes epithelial or endothelial cells, which undergo epithelialto-mesenchymal transition (EMT) or endothelial-to-mesenchymal transition (EndoMT), respectively; local tissue-residing fibroblasts (within the tissue where the fibrosis occurs); circulating bone marrow-derived fibrocytes; tissue-resident mesenchymal stem cells (MSCs); and smooth muscle cells. However, the relative contribution of each cell type to the formation of myofibroblasts in a fibrotic scar is still under debate ${ }^{180}$. For EMT and EndoMT, the organized dedifferentiation of epithelial cells occurs with a loss of polarity, adherence, and tight junctions through a process that is mainly driven by TGF $\beta 1$, fibroblast growth factor 2 (FGF2), insulin-like growth factor 2 (IGF2), and epidermal growth factor $(\mathrm{EGF})^{181-183}$. Almost $0.5 \%$ of the leukocytes in peripheral blood are fibrocytes, which can be identified by the expression of the haemotpoietic cell marker CD34, leukocyte markers (CD11b, CD13 and CD45), and fibroblast products (such as type I and III collagen and fibronectin); however, fibrocytes lack specific macrophage, dendritic cell or B cell markers. TGF $\beta 1$ and endothelin-1 stimulate the activation and differentiation of fibrocytes into myofibroblast-like cells (aSMA-positive) $)^{180}$. Tissue-resident MSCs can be distinguished from fibrocytes by their lack of haemotpoeitic and leukocyte marker expression and aSMA positivity ${ }^{15,180}$. During atheromatous plaque formation, smooth muscle cells have been shown to dedifferentiate into myofibroblasts and are considered to be an important contributor to the associated fibrosis ${ }^{154}$.

However, multiple studies in humans investigating the incidence of Peyronie's disease after penile fracture or in patients with a long history of forcefully bending the erect penis (taqaandan) did not show a correlation between trauma and Peyronie's disease ${ }^{151,152}$. This observation might suggest that several unknown genetic factors are involved in the development of Peyronie's disease.
A wound-healing process starts after each trauma as a result of injury of the resident endothelial cells, which in turn results in platelet activation, fibrin accumulation and release of pro-inflammatory molecules (for example, cytokines and chemokines) (FIC. 1). The activation of the coagulation system and release of fibrin is thought to have an important role in plaque formation in human Peyronie's disease ${ }^{96}$. The persistence of fibrin elicits an acute - and subsequent chronic - inflammatory response, and the subsequent production of profibrotic factors such as TGF $\beta 1$ and ROS induce the development of the fibrotic plaque. The role of endothelial damage in Peyronie's disease is evidenced by the observation that injection of fibrin into the space of Smith of the rat induces a Peyronie's disease-like lesion ${ }^{150}$. Similarly, injections of thrombin (which catalyses conversion of fibrinogen into fibrin) into the rat penis resulted in the formation of a fibrotic plaque ${ }^{150}$.

Activated platelets release a diverse set of growth factors, the most important of which is plateletderived growth factor (PDGF), a potent profibrotic molecule and chemoattractant for inflammatory cells. Inflammation occurs through the influx of cells from the innate and adaptive immune system; lymphocytes, polymorphonuclear leukocytes, eosinophils, basophils, $\mathrm{T}_{\mathrm{H}} 17$ cells, $\mathrm{T}_{\mathrm{H}} 2$ cells and macrophages are all attracted to the site of inflammation ${ }^{4,6,96}$. The presence of these immune cells at the site of tissue injury is essential for the normal wound-healing process, but they also cause the release of several toxic factors, including ROS and RNS that, if not cleared, can induce further tissue damage ${ }^{4}$.

Another important feature of fibrosis is the formation of myofibroblasts ${ }^{37}$. The cellular origin of myofibroblasts remains a subject of debate. Research over the past few decades has implicated several possible sources, including circulating bone-marrow derived cells, smooth muscle cells, local resident fibroblast pools, and epithelial or endothelial cells ${ }^{153,154}$ (FIG. 4). Human tunica albugineaderived fibroblasts have been shown to undergo a phenotypic switch into myofibroblasts after exposure to TGF $\beta 1$, after which they secrete ECM proteins, suggesting that they are suitable candidates for a source of locally-derived myofibroblasts ${ }^{7,150,155}$.

Myofibroblasts are the main ECM-producing cells, releasing a plethora of ECM products such as elastins, proteoglycans, collagens, fibronectins, fibrillins and tenascins $s^{153}$. After the proliferation phase, remodelling and contraction of the ECM occurs, which results in a curvature of the penis in Peyronie's disease. During the remodelling phase, type III collagen (which is prevalent during the proliferation phase) is replaced by type I collagen, causing a stabilization of the plaque. In some patients, the formation of calcifications or ossifications within the plaque ultimately occurs ${ }^{7,150,155}$.

Although innate immune cells secrete a wide range of pro-inflammatory growth factors and cytokines, the role of TGF $\beta 1$ in Peyronie's disease has been thoroughly investigated. The TGF $\beta 1$ pathway seems to have a crucial profibrotic role that is due, at least in part, to its ability to induce myofibroblast activation ${ }^{5,156}$. Indeed, TGF $\beta 1$ production also occurs during the progression 
of liver, lung, kidney, skin and cardiac fibrosis ${ }^{2,4}$. By contrast, inhibition of the TGF $\beta 1$ signalling pathway has been shown to reduce the development of fibrosis in many experimental models of Peyronie's disease ${ }^{7,150}$. The importance of TGF $\beta 1$ in the onset of Peyronie's disease is illustrated by the most commonly used rat model, in which recombinant TGF $\beta 1$ is injected into the space of Smith and the tunica albuginea, resulting in the upregulation of several pro-inflammatory factors such as C-C motif chemokine 2 (CCL2; also known as MCP1) and the development of a fibrotic plaque characterized by high levels of elastin and type III collagen within several weeks ${ }^{96}$.

Stem cell therapy for Peyronie's disease. Peyronie's disease was first described almost 250 years ago, but no satisfactory medical treatment currently exists in the acute phase before the full-blown chronic plaque is established ${ }^{11}$. However, experimental models have provided new insights into the pathophysiology and aetiology of the disease. To date, only four preclinical studies have evaluated the local injection of MSCs as a therapy for Peyronie's disease ${ }^{129-131,157}$ (TABLE 1). These studies tested the in vivo efficacy of local MSC injection using the most common model of Peyronie's disease, which is based on the local injection of TGF $\beta 1$ into the tunica albuginea of rats.

The potential therapeutic benefit of ADSCs in Peyronie's disease was first shown in 2013 (REF. ${ }^{131}$ ). Human ADSCs were injected into the tunica albuginea of rats 1 day after the local injection of TGF $\beta 1$ to mimic the acute phase and induce the elevated grade of inflammation that is necessary for the ADSCs to develop an anti-inflammatory phenotype. Treated rats had less elastosis and fibrosis of the tunica albuginea and less ED than untreated rats 5 weeks after local ADSC injection to the site of inflammation. The total elastin content decreased by $\sim 50 \%$ in the lesions of treated rats compared with that of untreated rats; in addition, the type III collagen content was reduced by $\sim 70 \%$ after ADSC injection. Moreover, corporal fibrosis near the tunica albuginea plaque was completely prevented by the ADSC treatment. This study provided a proof of principle for the efficacy of stem cells in the treatment of Peyronie's disease. However, most patients present to their health-care provider with disease in the chronic stage; thus, these results cannot be directly translated into clinical application.

Two preclinical studies ${ }^{129,130}$ have evaluated the efficacy of allogeneic ADSCs and genetically modified allogeneic ADSCs expressing human IFNa2b for the prevention and treatment of tunica albuginea fibrotic plaque tissue. ADSC treatment markedly decreased tunica albuginea fibrosis and improved erectile function at 6 weeks after injection in both prevention (immediate ADSC injection) and treatment (ADSC injection after 4 weeks) groups compared with untreated groups in both studies. Possible antifibrotic mechanisms were also investigated in the former study ${ }^{129}$. Local injection of ADSCs seemed to decrease the expression of TIMPs, promoting the production and activity of MMPs to break down the slowly growing plaque.
Finally, an in vitro study using rat tunica albugineaderived fibroblasts showed that, after TGF $\beta 1$-induced myofibroblast transformation, co-culture with allogeneic ADSCs inhibited their contractile and ECMproducing capabilities through inhibition of the SMAD and $\mathrm{RHO} / \mathrm{RHOA}$ signalling pathways ${ }^{157}$. Moreover, the production of MMP9, MMP13, MMP2 and MMP3 was upregulated following allogeneic ADSC coculture, indicative of collagen breakdown. As the final outcome parameter, the investigators showed an increase in myofibroblast apoptosis after allogeneic ADSC co-culture, which occurred via the elevated activity of caspase 3 and caspase 9.

Overall, qualitative preclinical data regarding the use of stem cells in Peyronie's disease is severely lacking. Additional knowledge and research on the pathophysiology of Peyronie's disease is urgently needed, which will lead to the development of improved disease models that more closely resemble the human situation.

\section{Urethral stricture}

Urethral strictures are characterized by an abnormal narrowing of the urethra caused by varying degrees of spongiofibrosis that functionally obstructs the lower urinary tract. Urethral stricture disease can markedly reduce a patient's quality of life by promoting genitourinary infection, impairing voiding and causing secondary bladder dysfunction ${ }^{9}$. Several aetiologies have been proposed and are categorized as iatrogenic, traumatic, inflammatory and idiopathic ${ }^{9}$. Since the advent of endourology and catheter usage, the prevalence of iatrogenic urethral strictures has surpassed that of inflammatory causes ${ }^{158}$.

The pathophysiological mechanisms underlying urethral stricture disease are poorly investigated and remain largely obscure, with only a few studies having investigated such mechanisms at the molecular level. Fibrosis in urethral strictures has been shown to be the result of an abnormal wound-healing process similar to that observed in other organs ${ }^{37}$. Moreover, a role for TGF $\beta 1$ in urethral fibrosis and stricture formation has been suggested; twofold to threefold higher urine levels of TGF $\beta 1$ and increased TGF $\beta$ receptor type 2 (TGF $\beta R 2$ ) expression have been reported in urethral strictural tissue compared with normal urethral tissue ${ }^{159}$.

Stem cell therapy for urethral stricture. The use of stem cells in urethral reconstructive urology has been an ongoing area of study ${ }^{160}$. Research has been focused solely on the regenerative property of stem cells. Various studies have attempted to regenerate lost urethral tissue using tissue engineering and stem cell bioscaffolding ${ }^{160}$.

To date, only two studies have described the efficacy of stem cell injection in a rat model of urethral stricture $^{31,133}$ (TABLE 1). In 2016, the first evidence that xenotransplantation of human ADSCs prevented urethral stricture formation and voiding impairment in a rat model of urethral stricture was published ${ }^{31}$. This model was first developed in 2015 (REF. ${ }^{161}$ ) and was established by combining injury of the spongy tissue with the simultaneous local injection of TGF $\beta 1$; this method induces fibrosis in the corpus spongiosum with an increase in collagen expression. In the 2016 study $^{31}$, the authors 
showed that this model of urethral stricture could induce urodynamic changes at 4 weeks after injury similar to those seen in human lower urinary tract obstruction (for example, increased voiding frequency and reduced bladder capacity suggestive of detrusor overactivity caused by bladder obstruction and detrusor hypertrophy). Local injection of human ADSCs 1 day after induction of the fibrotic reaction prevented the formation of spongiofibrosis. Masson's trichrome staining showed that ADSC injection preserved corpus spongiosum tissue architecture and promoted the almost complete normalization of type III collagen and elastin protein content ${ }^{31}$. These findings were further corroborated by the observation of preserved micturition function in treated animals. Moreover, the authors showed that the concentration of inducible nitric oxide synthase (iNOS) and eNOS were increased in the treated group compared with untreated animals. These findings were confirmed by another study ${ }^{133}$ using the same rat model of urethral stricture; however, autologous ADSCs were injected the day of TGF $\beta 1$ injection. Levels of urethral collagen type I and III collagen were markedly decreased in rats treated with ADSCs compared with untreated rats 2 weeks after induction of the fibrotic reaction.

Overall, urethral stricture research has been limited by the lack of representative in vitro and in vivo models owing to the complexity of the disease. Similar to Peyronie's disease, insufficient preclinical data exist to warrant qualitative clinical trials.

\section{Limitations of preclinical studies}

The rapidly expanding and promising body of preclinical research in stem cell medicine can provide a potential cure for fibrotic diseases such as lung, kidney and heart fibrosis. On the basis of the current evidence, stem cells could have a role in the treatment of penile fibrosis. However, the amount of research in this field is still small and is characterized by several limitations that might reduce the translational power of stem cells as treatments for penile fibrotic disorders.

Human wound-healing and repair mechanisms developed early in the evolutionary development of our species. Thus, wound-healing, and, by extension, fibrosis, involves a very complex network of interactions and includes many compensatory pathways. Accordingly, drugs that inhibit and/or influence only one factor in the fibrotic cascade have a small chance of clinical success $^{2,3,37}$. Conversely, stem cells can counteract fibrosis at multiple steps in the fibrotic pathway ${ }^{84}$, a characteristic that suggests their potential superiority over currently available treatments ${ }^{47}$

Epigenetic modifications have been increasingly recognized to have a potentially important role in the maintenance of an undifferentiated state in MSCs ${ }^{59,60}$. Further research into the regulation of DNA methylation and its role in stem cell differentiation might provide further insight into improving stem cell treatments ${ }^{59,60}$.

Most studies investigating penile fibrotic disorders evaluated fibrosis histopathologically using Masson's trichrome staining followed by quantitative image analysis. However, this method introduces potential biases ${ }^{162-164}$. First, and perhaps most importantly, Masson's trichrome staining is often evaluated by calculating the ratio of areas stained red to areas stained blue, assuming the red pigment stains only smooth muscle whereas the blue pigment stains only collagen. However, this assumption is erroneous given that all cells contain the intermediate filament keratin - including residual red blood cells, endothelial cells and platelets in the sinusoids - and will, therefore, stain red ${ }^{162-164}$. Ideally, Masson's trichrome staining should be combined with more quantitative techniques to detect fibrosis; depending on the type of tissue, such techniques include either quantitative PCR (qPCR) or western blotting for typical profibrotic genes and proteins, respectively, such as TGF $\beta 1, \alpha$-smooth muscle actin ( $\alpha$ SMA), collagen (type I and III), elastin and iNOS. Second, image analysis is subject to the selection of slides and areas by the investigator, which can induce some variation between studies; even when automated image analysis is used, this approach should be considered semi-quantitative.

The majority of studies exploring the efficacy of stem cells in the context of corpora cavernosa fibrosis showed that stem cells can prevent the onset of corpora cavernosa fibrosis. Conversely, only a few studies have shown that stem cell treatment was efficacious in reversing corpora cavernosa fibrosis ${ }^{126,128}$. In the clinical setting, most patients present with already established fibrosis, since clinical symptoms only occur when a large part of healthy tissue has been replaced by scar tissue. This point is of utmost importance for the translational application of stem cell treatment ${ }^{94}$; the same holds true for research regarding stem cell therapy for urethral strictures ${ }^{31,133}$. To date, only two preclinical studies $^{31,133}$ have explored the efficacy of xenogeneic ADSCs in preventing urethral fibrosis, without validation by other studies.

Only four studies have explored the efficacy of stem cells in Peyronie's disease, and reported similar findings ${ }^{129-131,157}$. Despite these studies showing that ADSCs can prevent and even treat tunica albuginea fibrosis, several limitations jeopardize their translational potential. Of note, the TGF $\beta 1$ rat model of Peyronie's disease differs from the human Peyronie's disease in three main pathophysiological aspects, which should be taken into account: rats do not develop a curvature of the penis; the TGF $\beta 1$ injection does not induce fibrin accumulation in rats, which occurs in human tunica albuginea plaques, meaning that TGF $\beta 1$ is probably not the sole initiator of Peyronie's disease fibrosis; and rat tunica albuginea plaques dissolve spontaneously 60-90 days after induction of injury, which makes it difficult to study the chronic stage of the disease ${ }^{150}$. Importantly, different injection procedures (needle size, injection location and technique, and extravasation of TGF $\beta 1$ into the corporal tissue) could induce different degrees of corporal fibrosis and ED that might not be related to fibrosis of the tunica albuginea ${ }^{150}$.

In addition, several issues associated with stem cell treatment remain to be explored. Intracavernosal injection is the most frequently used route of stem cell delivery in preclinical studies (TABLE 1); however, intravenous injection has also proved to be effective and should be further examined. Further evaluation into 
the comparative superiority of allogeneic versus autologous versus xenogeneic stem cell injection is also warranted. Moreover, ADSCs are the most commonly used type of stem cell, but adipose-derived SVF seems to be a better choice given the lower risk of contamination ${ }^{82}$. However, this observation needs to be clarified through comparative studies. The timing of stem cell injection is another unresolved issue, particularly as stem cells seem to show an antifibrotic phenotype only when they are in an inflammatory environment ${ }^{35}$. Finally, the dosage of stem cells in preclinical studies is arbitrary, and whether the number of stem cells injected can influence the stem cell phenotype and local inflammatory environment is not yet clear.

\section{Conclusions}

To date, the clinical application and investigation of conventional antifibrotic therapies has yielded limited results. Conventional approaches focus on the inhibition of one small cog in the large machinery of fibrosis, resulting in the activation of auxiliary pathways that counteract the effects of these antifibrotic drugs. However, the use of stem cells in translational research has the potential to exert antifibrotic functions on several levels by modulating the host response. Despite the amount of research on stem cells and penile fibrosis, the field is still in its infancy and is subject to many limitations. Most preclinical research regarding stem cells in penile fibrosis has focused on corpora cavernosa fibrosis owing to its clear pathophysiology (iatrogenic postprostatectomy ED and corpora cavernosa fibrosis) and representative animal models. Conversely, Peyronie's disease and urethral stricture disease research have been limited by poor disease models and unvalidated findings. Thus, the treatment of corpora cavernosa fibrosis with stem cells seems to be the closest to potential clinical application given additional studies evaluating the efficacy, dosage, timing and route of administration of stem cells or SVF.

Published online: 26 October 2018
1. Wynn, T. Cellular and molecular mechanisms of fibrosis. J. Pathol. 214, 199-210 (2008).

2. Wynn, T. A. Mechanisms of fibrosis: therapeutic translation for fibrotic disease. Nat. Med. 18 1028-1040 (2013)

3. Rockey, D. C., Bell, P. D. \& Hill, J. A. Fibrosis - a common pathway to organ injury and failure. N. Engl. J. Med. 372, 1138-1149 (2015).

4. Cannito, S., Novo, E. \& Parola, M. Therapeutic pro-fibrogenic signaling pathways in fibroblasts. Adv. Drug Deliv. Rev. 121, 57-84 (2017).

5. Hinz, B. The extracellular matrix and transforming growth factor- $\beta 1$ : tale of a strained relationship. Matrix Biol. 47, 54-65 (2015)

6. Gonzalez-Cadavid, N. F. \& Rajfer, J. Treatment of Peyronie's disease with PDE5 inhibitors: an antifibrotic strategy. Nat. Rev. Urol. 7, 215-221 (2010).

7. Gonzalez-Cadavid, N. F. \& Rajfer, J. Experimental models of peyronie's disease. Implications for new therapies. J. Sex. Med. 6, 303-313 (2009).

8. Gonzalez-Cadavid, N. F. Mechanisms of penile fibrosis. J. Sex. Med. 6, 353-362 (2009).

9. Mundy, A. R. \& Andrich, D. E. Urethral strictures. BJU Int. 107, 6-26 (2011).

10. Kucukdurmaz, F. et al. Duration of priapism is associated with increased corporal oxidative stress and antioxidant enzymes in a rat model. Andrologia 48, 374-379 (2016).

11. Garaffa, G., Trost, L. W., Serefoglu, E. C., Ralph, D. \& Hellstrom, W. J. G. Understanding the course of Peyronie's disease. Int. J. Clin. Pract. 67, 781-788 (2013).

12. Caplan, A. I. \& Correa, D. The MSC: an injury drugstore Cell Stem Cell 9, 11-15 (2011).

13. Caplan, A. I. MSCs: the sentinel and safe-guards of injury. J. Cell. Physiol. 231, 1413-1416 (2016).

14. Singer, N. G. \& Caplan, A. I. Mesenchymal stem cells: mechanisms of inflammation. Annu. Rev. Pathol. Mech. Dis. 6, 457-478 (2011).

15. da Silva Meirelles, L., Fontes, A. M., Covas, D. T $\&$ Caplan, A. I. Mechanisms involved in the therapeutic properties of mesenchymal stem cells. Cytokine Growth Factor Rev. 20, 419-427 (2009).

16. Lim, R., Ricardo, S. D. \& Sievert, W. Cell-based therapies for tissue fibrosis. Front. Pharmacol. 8, 633 (2017).

17. El Agha, E. et al. Mesenchymal stem cells in fibrotic disease. Cell Stem Cell 21, 166-177 (2017).

18. Ghieh, F. et al. The use of stem cells in burn wound healing: a review. Biomed. Res. Int. 2015, 1-9 (2015).

19. Eom, Y. W., Shim, K. Y. \& Baik, S. K. Mesenchymal stem cell therapy for liver fibrosis. Kor. J. Intern. Med. 30, 580-589 (2015)

20. Usunier, B., Benderitter, M., Tamarat, R. \& Chapel, A. Management of fibrosis: the mesenchymal stromal cells breakthrough. Stem Cells Int. 2014, 1-26 (2014).

21. Geiger, S., Hirsch, D. \& Hermann, F. G. Cell therapy for lung disease. Eur. Respir. Rev. 26, 170044 (2017).
22. Hostettler, K. E. et al. Multipotent mesenchymal stem cells in lung fibrosis. PLOS ONE 12, e0181946 (2017).

23. Sitanggang, E. J., Antarianto, R. D., Jusman, S. W. A Pawitan, J. A. \& Jusuf, A. A. Bone marrow stem cells anti-liver fibrosis potency: inhibition of hepatic stellate cells activity and extracellular matrix deposition. Int. J. Stem Cells 10, 69-75 (2017)

24. Milosavljevic, N. et al. Mesenchymal stem cells attenuate liver fibrosis by suppressing Th 17 cells - an experimental study. Transpl. Int. 31, 102-115 (2018).

25. Lou, G., Chen, Z., Zheng, M. \& Liu, Y. Mesenchymal stem cell-derived exosomes as a new therapeutic strategy for liver diseases. Exp. Mol. Med. 49, e346 (2017).

26. Matsui, F. et al. Mesenchymal stem cells protect against obstruction-induced renal fibrosis by decreasing STAT3 activation and STAT3-dependent MMP-9 production. Am. J. Physiol. Renal Physiol. 312, F25-F32 (2017).

27. Kuppe, C. \& Kramann, R. Role of mesenchymal stem cells in kidney injury and fibrosis. Curr. Opin. Nephrol. Hypertens. 25, 372-377 (2016)

28. Reinders, M. E. J., de Fijter, J. W. \& Rabelink, T. J. Mesenchymal stromal cells to prevent fibrosis in kidney transplantation. Curr. Opin. Organ. Transplant. 19, 54-59 (2014).

29. Wu, S.-Z. et al. Paracrine effect of CXCR4 overexpressing mesenchymal stem cells on ischemic heart injury. Cell Biochem. Funct. 35, 113-123 (2017).

30. Michler, R. E. Stem cell therapy for heart failure. Methodist Debakey Cardiovasc. J. 9, 187-194 (2013).

31. Castiglione, F. et al. Adipose-derived stem cells counteract urethral stricture formation in rats. Eur. Urol. 70, 1032-1041 (2016).

32. Soebadi, M. A., Milenkovic, U., Weyne, E. \& Castiglione, F. Stem cells in male sexual dysfunction are we getting somewhere? Sex. Med. Rev. 5 222-235 (2016).

33. Soebadi, M. A., Moris, L., Castiglione, F., Weyne, E. $\&$ Albersen, M. Advances in stem cell research for the treatment of male sexual dysfunctions. Curr. Opin. Urol. 26, 129-139 (2016).

34. Dellis, A. \& Papatsoris, A. Stem cell therapy for the treatment of Peyronie's disease. Expert Opin. Biol. Ther. 17, 407-413 (2017).

35. Bernardo, M. E. \& Fibbe, W. E. Mesenchymal stromal cells: sensors and switchers of inflammation. Cell Stem Cell 13, 392-402 (2013).

36. Vannella, K. M. \& Wynn, T. A. Mechanisms of organ injury and repair by macrophages. Annu. Rev. Physiol. 79, 593-617 (2017).

37. Wynn, T. A. Common and unique mechanisms regulate fibrosis in various fibroproliferative diseases. J. Clin. Invest. 117, 524-529 (2007).

38. Duffield, J. S., Lupher, M., Thannickal, V. J. \& Wynn, T. A Host responses in tissue repair and fibrosis. Annu. Rev. Pathol. Mech. Dis. 8, 241-276 (2013).
39. Schneider, R. K. et al. Gli $1^{+}$mesenchymal stromal cells are a key driver of bone marrow fibrosis and an important cellular therapeutic target. Cell Stem Cell 20, 785-800 (2017)

40. Marshall, R. P., Simpson, J. K. \& Lukey, P. T. Strategies for biomarker discovery in fibrotic disease. Biochim. Biophys. Acta 1832, 1079-1087 (2013).

41. Tzouvelekis, A. et al. Longitudinal "real-world" outcomes of pirfenidone in idiopathic pulmonary fibrosis in Greece. Front. Med. 4, 213 (2017).

42. Tzouvelekis, A. et al. Safety and efficacy of nintedanib in idiopathic pulmonary fibrosis: a real-life observational study in Greece. Pulm. Pharmacol. Ther. 49, 61-66 (2018).

43. Voog, J. \& Jones, D. L. Stem cells and the niche: a dynamic duo. Cell Stem Cell 6, 103-115 (2010).

44. Wu, J. \& Izpisua Belmonte, J. C. Dynamic pluripotent stem cell states and their applications. Cell Stem Cell 17, 509-525 (2015)

45. Enver, T., Pera, M., Peterson, C. \& Andrews, P. W. Stem cell states, fates, and the rules of attraction. Cell Stem Cell 4, 387-397 (2009).

46. Bonfield, T. L. \& Caplan, A. I. Adult mesenchymal stem cells: an innovative therapeutic for lung diseases. Discov. Med. 9, 337-345 (2010).

47. DiMarino, A. M., Caplan, A. I. \& Bonfield, T. L. Mesenchymal stem cells in tissue repair. Front. Immunol. 4, 201 (2013).

48. Bianco, P., Robey, P. G. \& Simmons, P. J. Mesenchymal stem cells: revisiting history, concepts, and assays. Cell Stem Cell 2, 313-319 (2008).

49. Caplan, A. I. \& Dennis, J. E. Mesenchymal stem cells as trophic mediators. J. Cell. Biochem. 98, 1076-1084 (2006).

50. Guimarães-Camboa, N. et al. Pericytes of multiple organs do not behave as mesenchymal stem cells in vivo. Cell Stem Cell 20, 345-359.e5 (2017).

51. Thomas, H., Cowin, A. J. \& Mills, S. J. The importance of pericytes in healing: wounds and other pathologies. Int. J. Mol. Sci. 18, E1129 (2017).

52. Różycka, J., Brzōska, E. \& Skirecki, T. Aspects of pericytes and their potential therapeutic use. Postepy Hig. Med. Dosw. 71, 186-197 (2017).

53. Ferland-McCollough, D., Slater, S., Richard, J., Reni, C. \& Mangialardi, G. Pericytes, an overlooked player in vascular pathobiology. Pharmacol. Ther 171, 30-42 (2017).

54. Ankrum, J. A., Ong, J. F. \& Karp, J. M. Mesenchymal stem cells: immune evasive, not immune privileged. Nat. Biotechnol. 32, 252-260 (2014).

55. Shi, Y. et al. How mesenchymal stem cells interact with tissue immune responses. Trends Immunol. 33 136-143 (2012).

56. Trounson, A. \& McDonald, C. Stem cell therapies in clinical trials: progress and challenges. Cell Stem Cell 17, 11-22 (2015).

57. Dominici, M. et al. Minimal criteria for defining multipotent mesenchymal stromal cells. The International Society for Cellular Therapy position statement. Cytotherapy 8, 315-317 (2006). 
58. Inaba, M. \& Yamashita, Y. M. Asymmetric stem cell division: precision for robustness. Cell Stem Cell 11 461-469 (2012)

59. Khavari, D. A., Sen, G. L. \& Rinn, J. L. DNA methylation and epigenetic control of cellular differentiation. Cell Cycle 9, 3880-3883 (2010).

60. Collas, P. Programming differentiation potential in mesenchymal stem cells. Epigenetics 5, 476-482 (2010)

61. Sorrell, J. M. \& Caplan, A. I. Topical delivery of mesenchymal stem cells and their function in wounds. Stem Cell Res. Ther. 1, 30 (2010).

62. Maxson, S., Lopez, E. A., Yoo, D., DanilkovitchMiagkova, A. \& LeRoux, M. A. Concise Review: Role of mesenchymal stem cells in wound repair. Stem Cells Transl Med. 1, 142-149 (2012).

63. Hanson, S. E. Mesenchymal stem cells: a multimodality option for wound healing. Adv. Wound Care 1, 153-158 (2012)

64. Mattoli, S., Bellini, A. \& Schmidt, M. The role of a human hematopoietic mesenchymal progenitor in wound healing and fibrotic diseases and implications for therapy. Curr. Stem Cell Res. Ther. 4, 266-280 (2009).

65. Larson, B. J., Longaker, M. T. \& Lorenz, H. P. Scarless fetal wound healing: a basic science review. Plast. Reconstr. Surg. 126, 1172-1180 (2010).

66. Leavitt, T. et al. Scarless wound healing: finding the right cells and signals. Cell Tissue Res. 365, 483-493 (2016).

67. Cerqueira, M. T., Pirraco, R. P. \& Marques, A. P. Stem cells in skin wound healing: are we there yet? Adv. Wound Care 5, 164-175 (2016).

68. Pinggera, G.-M., Rehder, P., Bartsch, G. \& Gozzi, C. Harnröhrentraumen. Urologe 44, 883-897 (2005)

69. Mooney, D. J. \& Vandenburgh, H. Cell delivery mechanisms for tissue repair. Cell Stem Cell 2 , 205-213 (2008)

70. Wynn, T. A. $\&$ Vannella, K. M. Macrophages in tissue repair, regeneration, and fibrosis. Immunity $\mathbf{4 4}$ 450-462 (2016)

71. Wang, Y. et al. Adipose derived mesenchymal stem cells transplantation via portal vein improves microcirculation and ameliorates liver fibrosis induced by $\mathrm{CCl}_{4}$ in rats. J. Trans/ Med. 10, 133 (2012).

72. Wu, Y. et al. Bone marrow-derived mesenchymal stem cell attenuates skin fibrosis development in mice. Int. Wound J. 11, 701-710 (2014)

73. Wu, Y. et al. Mesenchymal stem cells suppress fibroblast proliferation and reduce skin fibrosis through a TGF- $\beta 3$-dependent activation. Int. J. Low. Extrem. Wounds 14, 50-62 (2015).

74. Williams, A. R. et al. Durable scar size reduction due to allogeneic mesenchymal stem cell therapy regulates whole-chamber remodeling. J. Am. Heart Assoc. 2, e000140 (2013)

75. Hashimoto, N., Jin, H., Liu, T., Chensue, S. W. \& Phan, S. H. Bone marrow-derived progenitor cells in pulmonary fibrosis. J. Clin. Invest. 113, 243-252 (2004).

76. Jurado, M. et al. Adipose tissue-derived mesenchymal stromal cells as part of therapy for chronic graftversus-host disease: a phase I/II study. Cytotherapy 19, 927-936 (2017)

77. Owen Pickrell, W. \& Robertson, N. P. Stem cell treatment for multiple sclerosis. J. Neurol. 263 2145-2147 (2016)

78. Lamo-Espinosa, J. M. et al. Intra-articular injection of two different doses of autologous bone marrow mesenchymal stem cells versus hyaluronic acid in the treatment of knee osteoarthritis: multicenter randomized controlled clinical trial (phase I/II). J. Trans/ Med. 14, 246 (2016).

79. Lindsay, J. O. et al. Autologous stem-cell transplantation in treatment-refractory Crohn's disease: an analysis of pooled data from the ASTIC trial. Lancet Gastroenterol. Hepatol. 2, 399-406 (2017).

80. Fandel, T. M. et al. Transplanted human stem cellderived interneuron precursors mitigate mouse bladder dysfunction and central neuropathic pain after spinal cord injury. Cell Stem Cell 19, 544-557 (2016).

81. Ranganath, S. H., Levy, O., Inamdar, M. S. \& Karp, J. M Harnessing the mesenchymal stem cell secretome for the treatment of cardiovascular disease. Cell Stem Cell 10, 244-258 (2012).

82. Gupta, M. K. \& Ajay, A. K. Fat on sale: role of adiposederived stem cells as anti-fibrosis agent in regenerative medicine. Stem Cell Res. Ther. 6, 233 (2015).

83. Cheng, S.-L., Lin, C.-H. \& Yao, C.-L. Mesenchymal stem cell administration in patients with chronic obstructive pulmonary disease: state of the science. Stem Cells Int 2017, 1-14 (2017)
84. Jackson, W. M., Nesti, L. J. \& Tuan, R. S. Mesenchyma stem cell therapy for attenuation of scar formation during wound healing. Stem Cell Res. Ther. 3, 20 (2012).

85. Aurora, A. B. $\&$ Olson, E. N. Immune modulation of stem cells and regeneration. Cell Stem Cell 15, 14-25 (2014).

86. Bogdan, C. Nitric oxide synthase in innate and adaptive immunity: an update. Trends Immunol. 36 161-178 (2015).

87. Oshimori, N. \& Fuchs, E. The harmonies played by TGF- $\beta$ in stem cell biology. Cell Stem Cell 11, 751-764 (2012).

88. Sreeramkumar, V., Fresno, M. \& Cuesta, N. Prostaglandin $\mathrm{E}_{2}$ and $\mathrm{T}$ cells: friends or foes? Immunol. Cell Biol. 90, 579-586 (2012).

89. Nakanishi, M. \& Rosenberg, D. W. Multifaceted roles of PGE2 in inflammation and cancer. Semin. Immunopathol. 35, 123-137 (2013).

90. Kalinski, P. Regulation of immune responses by prostaglandin E2. J. Immunol. 188, 21-28 (2012).

91. Braga, T. T., Agudelo, J. S. H. \& Camara, N. O. S Macrophages during the fibrotic process: M2 as friend and foe. Front. Immunol. 6, 602 (2015).

92. Galli, S. J., Borregaard, N. \& Wynn, T. A. Phenotypic and functional plasticity of cells of innate immunity: macrophages, mast cells and neutrophils. Nat. Immunol. 12, 1035-1044 (2011).

93. Sziksz, E. et al. Fibrosis related inflammatory mediators: role of the IL-10 cytokine family. Mediators Inflamm. 2015, 764641 (2015).

94. Dean, R. C. \& Lue, T. F. Physiology of penile erection and pathophysiology of erectile dysfunction. Urol. Clin. North Am. 32, 379-395 (2005)

95. Lue, T. F., Brant, W. O., Shindel, A. \& Bella, A. J. Sexual Dysfunction in Diabetes (eds De Groot, L. J., Chrousos, G., Dungan, K. et al) (MDText.com, Inc., 2000)

96. Gonzalez-Cadavid, N. F. \& Rajfer, J. Mechanisms of disease: new insights into the cellular and molecular pathology of Peyronie's disease. Nat. Clin. Pract. Urol. 2, 291-297 (2005).

97. Haglind, E. et al. Urinary incontinence and erectile dysfunction after robotic versus open radical prostatectomy: a prospective, controlled, nonrandomised trial. Eur. Urol. 68, 216-225 (2015).

98. Yafi, F. A. et al. Erectile dysfunction. Nat. Rev. Dis. Primers 2, 16003 (2016).

99. Ferrini, M. G. et al. Fibrosis and loss of smooth muscle in the corpora cavernosa precede corporal venoocclusive dysfunction (CVOD) induced by experimental cavernosal nerve damage in the rat. J. Sex. Med. 6 415-428 (2009)

100. Fode, M., Ohl, D. A., Ralph, D. \& Sønksen, J. Penile rehabilitation after radical prostatectomy: what the evidence really says. BJU Int. 112, 998-1008 (2013)

101. Sopko, N. A. \& Burnett, A. L. Erection rehabilitation following prostatectomy - current strategies and future directions. Nat. Rev. Urol. 13, 216-225 (2016)

102. Hannan, J. L. et al. Caspase-3 dependent nitrergic neuronal apoptosis following cavernous nerve injury is mediated via RhoA and ROCK activation in major pelvic ganglion. Sci. Rep. 6, 29416 (2016)

103. Albersen, M. et al. Pentoxifylline promotes recovery of erectile function in a rat model of postprostatectomy erectile dysfunction. Eur. Urol. 59, 286-296 (2011).

104. Chitaley, K. et al. Antagonism of Rho-kinase stimulates rat penile erection via a nitric oxide-independent pathway. Nat. Med. 7, 119-122 (2001).

105. Chitaley, K., Webb, R. C. \& Mills, T. M. Rho-kinase as a potential target for the treatment of erectile dysfunction. Drug News Perspect. 14, 601-606 (2001).

106. Chitaley, K., Webb, R. \& Mills, T. RhoA/Rho-kinase: a novel player in the regulation of penile erection Int. J. Impot. Res. 13, 67-72 (2001).

107. Martínez-Salamanca, J. I. et al. $\alpha_{14}$-adrenergic receptor antagonism improves erectile and cavernosal responses in rats with cavernous nerve injury and enhances neurogenic responses in human corpus cavernosum from patients with erectile dysfunction secondary to radical prostatectomy. J. Sex. Med. 13 , 1844-1857 (2016)

108. Martínez-Salamanca, J. I., Mueller, A., Moncada, I., Carballido, J. \& Mulhall, J. P. Penile prosthesis surgery in patients with corporal fibrosis: a state of the art review. J. Sex. Med. 8, 1880-1889 (2011).

109. Wang, X. et al. Hypoxia precondition promotes adipose-derived mesenchymal stem cells based repair of diabetic erectile dysfunction via augmenting angiogenesis and neuroprotection. PLOS ONE 10, e0118951 (2015).
110. Liu, T. et al. Hepatocyte growth factor-modified adipose tissue-derived stem cells improve erectile function in streptozotocin-induced diabetic rats. Growth Factors 33, 282-289 (2015)

111. Huang, Y.-C. et al. The effects of adipose-derived stem cells in a rat model of tobacco-associated erectile dysfunction. PLOS ONE 11, e0156725 (2016).

112. Kovanecz, I. et al. Separate or combined treatments with daily sildenafil, molsidomine, or muscle-derived stem cells prevent erectile dysfunction in a rat model of cavernosal nerve damage. $J$. Sex. Med $\mathbf{9}$ 2814-2826 (2012).

113. Ying, C. et al. Erectile function restoration after repair of resected cavernous nerves by adipose-derived stem cells combined with autologous vein graft in rats. Cell. Mol. Neurobiol. 34, 393-402 (2014).

114. Chen, X. et al. Neurotrophic effect of adipose tissuederived stem cells on erectile function recovery by pigment epithelium-derived factor secretion in a rat model of cavernous nerve injury. Stem Cells Int. 2016 , 1-12 (2016).

115. Albersen, M. et al. Injections of adipose tissue-derived stem cells and stem cell lysate improve recovery of erectile function in a rat model of cavernous nerve injury. J. Sex. Med. 7, 3331-3340 (2010).

116. Kim, I. G. et al. Effect of an adipose-derived stem cell and nerve growth factor-incorporated hydrogel on recovery of erectile function in a rat model of cavernous nerve injury. Tissue Eng. Part A 19, 14-23 (2013).

117. You, D. et al. Comparative study of autologous stromal vascular fraction and adipose-derived stem cells for erectile function recovery in a rat model of cavernous nerve injury. Stem Cells Trans/ Med. 4, 351-358 (2015).

118. Martínez-Salamanca, J. I. et al. Dual strategy with oral phosphodiesterase type 5 inhibition and intracavernosal implantation of mesenchymal stem cells is superior to individual approaches in the recovery of erectile and cavernosal functions after cavernous nerve injury in rats. J. Sex. Med 13, 1-11 (2016).

119. Ryu, J.-K. et al. Intracavernous delivery of clonal mesenchymal stem cells rescues erectile function in the streptozotocin-induced diabetic mouse. Andrology 4, 172-184 (2016)

120. Qiu, X. et al. Both immediate and delayed intracavernous injection of autologous adipose-derived stromal vascular fraction enhances recovery of erectile function in a rat model of cavernous nerve injury. Eur. Urol. 62, 720-727 (2012).

121. Ryu, J. et al. Intracavernous delivery of clonal mesenchymal stem cells restores erectile function in a mouse model of cavernous nerve injury. J. Sex. Med. $11,411-423$ (2014)

122. Jeong, H. H. et al. Combined therapeutic effect of udenafil and adipose-derived stem cell (ADSC)/brain derived neurotrophic factor (BDNF)-membrane system in a rat model of cavernous nerve injury. Urology $\mathbf{8 1}$ 1108.e7-1108.e14 (2013).

123. Fandel, T. M. et al. Recruitment of intracavernously injected adipose-derived stem cells to the major pelvic ganglion improves erectile function in a rat model of cavernous nerve injury. Eur. Urol. 61, 201-210 (2012).

124. Ying, C., Yang, M., Zheng, X., Hu, W. \& Wang, X. Effects of intracavernous injection of adipose-derived stem cells on cavernous nerve regeneration in a rat model. Cell. Mol. Neurobiol. 33, 233-240 (2013).

125. You, D. et al. Periprostatic implantation of human bone marrow-derived mesenchymal stem cells potentiates recovery of erectile function by intracavernosal injection in a rat model of cavernous nerve injury. Urology 81, 104-110 (2013).

126. You, D. et al. Bone marrow-derived mesenchymal stromal cell therapy in a rat model of cavernous nerve injury: preclinical study for approval. Cytotherapy 18 870-880 (2016)

127. Zhu, J.-Q. et al. Therapeutic potential of human umbilical cord blood mesenchymal stem cells on erectile function in rats with cavernous nerve injury. Biotechnol. Lett. 37, 1515-1525 (2015).

128. Song, L. et al. BDNF-hypersecreting human umbilical cord blood mesenchymal stem cells promote erectile function in a rat model of cavernous nerve electrocautery injury. Int. Urol. Nephrol. 48, 37-45 (2016).

129. Gokce, A. et al. Adipose tissue-derived stem cell therapy for prevention and treatment of erectile dysfunction in a rat model of Peyronie's disease. Andrology 2, 244-251 (2014). 
130. Gokce, A. et al. Intratunical injection of genetically modified adipose tissue-derived stem cells with human interferon $a-2 b$ for treatment of erectile dysfunction in a rat model of tunica albugineal fibrosis. J. Sex. Med. 12, 1533-1544 (2015)

131. Castiglione, F. et al. Intratunical injection of human adipose tissue-derived stem cells prevents fibrosis and is associated with improved erectile function in a rat model of Peyronie's disease. Eur. Urol. 63, 551-560 (2013).

132. Ouyang, B. et al. Human urine-derived stem cells alone or genetically-modified with FGF2 improve type 2 diabetic erectile dysfunction in a rat model. PLOS ONE 9, e92825 (2014).

133. Sangkum, P. et al. Effect of adipose tissue-derived stem cell injection in a rat model of urethral fibrosis. Can. Urol. Assoc. J. 10, E175-E180 (2016).

134. Levy, J. A., Marchand, M., Iorio, L., Cassini, W. $\&$ Zahalsky, M. P. Determining the feasibility of managing erectile dysfunction in humans with placental-derived stem cells. J. Am. Osteopath. Assoc. 116, e1 (2016)

135. Yang, Q. et al. Transplantation of human urine-derived stem cells transfected with pigment epithelium-derived factor to protect erectile function in a rat model of cavernous nerve injury. Cell Transplant. 25, 1987-2001 (2016)

136. Cengiz, T. et al. Intracavernous injection of human umbilical cord blood mononuclear cells improves erectile dysfunction in streptozotocin-induced diabetic rats. J. Sex. Med. 14, 50-58 (2017).

137. Shan, H.-T. et al. Combination of low energy shock wave therapy and bone marrow mesenchymal stem cell transplantation to improve the erectile function of diabetic rats. Asian J. Androl. 0, 0 (2016).

138. Wang, X. et al. Combination of mesenchymal stem cell injection with icariin for the treatment of diabetesassociated erectile dysfunction. PLOS ONE 12, e0174145 (2017).

139. Liu, G. et al. Correction of diabetic erectile dysfunction with adipose derived stem cells modified with the vascular endothelial growth factor gene in a rodent diabetic model. PLOS ONE 8, e 72790 (2013).

140. Kovanecz, I. et al. Implanted muscle-derived stem cells ameliorate erectile dysfunction in a rat model of type 2 diabetes, but their repair capacity is impaired by their prior exposure to the diabetic milieu. J. Sex. Med. 13, 786-797 (2016)

141. Garcia, M. M. et al. Treatment of erectile dysfunction in the obese type 2 diabetic ZDF rat with adipose tissue-derived stem cells. J. Sex. Med. 7, 89-98 (2010).

142. Yun, Y.-R. et al. Fibroblast growth factors: biology, function, and application for tissue regeneration. J. Tissue Eng. 2010, 218142 (2010).

143. Matsuda, Y. et al. Intravenous infusion of bone marrow-derived mesenchymal stem cells reduces erectile dysfunction following cavernous nerve injury in rats. Sex. Med. 6, 49-57 (2018).

144. Yang, J. et al. Adipose-derived stem cells improve erectile function partially through the secretion of IGF-1, bFGF, and VEGF in aged rats. Andrology 6 , 498-509 (2018)

145. Albersen, M., Weyne, E. \& Bivalacqua, T. J. Stem cell therapy for erectile dysfunction: progress and future directions. Sex. Med. Rev. 1, 50-64 (2013).

146. Fang, J. et al. Combined transplantation of mesenchymal stem cells and endothelial progenitor cells restores cavernous nerve injury-related erectile dysfunction. J. Sex. Med. 15, 284-295 (2018).

147. Graziottin, T. M. The pathophysiology of Peyronie's disease: beyond the Smith's space. Int. Braz. J. Urol. 41, 1040-1042 (2015)

148. Ralph, D., Cellek, S. \& Stebbeds, W. Solving a bottleneck in animal models of Peyronie's disease. Asian J. Androl. 16, 639 (2014).

149. Cerruto, M. A. et al. Animal experimental model of Peyronie's disease: a pilot study. Arch. Ital. Urol. Androl. 85, 28 (2013).

150. Chung, E., De Young, L. \& Brock, G. B. Rat as an animal model for Peyronie's disease research: a review of current methods and the peer-reviewed literature. Int. J. Impot. Res. 23, 235-241 (2011).

151. Zargooshi, J. Trauma as the cause of Peyronie's disease: penile fracture as a model of trauma. J. Urol. 172, 186-188 (2004).

152. Acikgoz, A. et al. Relationship between penile fracture and Peyronie's disease: a prospective study Int. J. Impot. Res. 23, 165-172 (2011).

153. Mack, M. \& Yanagita, M. Origin of myofibroblasts and cellular events triggering fibrosis. Kidney Int. $\mathbf{8 7}$, 297-307 (2015)

154. Bennett, M. R., Sinha, S. \& Owens, G. K. Vascular smooth muscle cells in atherosclerosis. Circ. Res. 118 692-702 (2016)

155. Vernet, D. et al. Evidence that osteogenic progenitor cells in the human tunica albuginea may originate from stem cells: implications for Peyronie disease. Biol. Reprod. 73, 1199-1210 (2005)

156. Tomasek, J. J., Gabbiani, G., Hinz, B., Chaponnier, C. \& Brown, R. A. Myofibroblasts and mechano regulation of connective tissue remodelling. Nat. Rev. Mol. Cell. Biol. 3, 349-363 (2002).

157. Jiang, H., Gao, Q., Che, X. \& Zhu, L. Inhibition of penile tunica albuginea myofibroblasts activity by adipose - derived stem cells. Exp. Ther. Med. 14 5149-5156 (2017).

158. Latini, J. M., McAninch, J. W., Brandes, S. B., Chung, J. Y. \& Rosenstein, D. SIU/ICUD Consultation on urethral strictures: epidemiology, etiology, anatomy, and nomenclature of urethral stenoses, strictures, and pelvic fracture urethral disruption injuries. Urology 83, S1-S7 (2014)

159. Xie, H., Feng, C., Fu, Q., Sa, Y.-L. \& Xu, Y.-M. Crosstalk between TCF- $\beta 1$ and CXCR3 signaling during urethral fibrosis. Mol. Cell. Biochem. 394, 283-290 (2014).

160. de Kemp, V., de Graaf, P., Fledderus, J. O., Ruud Bosch, J. L. H. \& de Kort, L. M. O. Tissue engineering for human urethral reconstruction: systematic review of recent literature. PLOS ONE 10 , e0118653 (2015).

161. Sangkum, P. et al. Transforming growth factor- $\beta 1$ induced urethral fibrosis in a rat model. J. Urol. 194, 820-827 (2015)

162. Marcos, R., Bragança, B. \& Fontes-Sousa, A. P. Image analysis or stereology. J. Histochem. Cytochem. 63 734-736 (2015)

163. Farris, A. B. et al. Morphometric and visual evaluation of fibrosis in renal biopsies. J. Am. Soc. Nephrol. 22 176-186 (2011)

164. Huang, Y. et al. Image analysis of liver collagen using sirius red is more accurate and correlates better with serum fibrosis markers than trichrome. Liver Int. 33, 1249-1256 (2013).

165. Barrientos, S., Stojadinovic, O., Golinko, M. S., Brem, H. \& Tomic-Canic, M. Perspective article: Growth factors and cytokines in wound healing. Wound Repair Regen. 16, 585-601 (2008)
166. Li, Y. et al. Severe lung fibrosis requires an invasive fibroblast phenotype regulated by hyaluronan and CD44. J. Exp. Med. 208, 1459-1471 (2011).

167. Wynn, T. A., Chawla, A. \& Pollard, J. W. Macrophage biology in development, homeostasis and disease. Nature 496, 445-455 (2013).

168. Crotty, S. A brief history of T cell help to B cells. Nat. Rev. Immunol. 15, 185-189 (2015).

169. Novo, E. et al. Proangiogenic cytokines as hypoxiadependent factors stimulating migration of human hepatic stellate cells. Am. J. Pathol. 170, 1942-1953 (2007).

170. Parola, M., Marra, F. \& Pinzani, M. Myofibroblast-like cells and liver fibrogenesis: emerging concepts in a rapidly moving scenario. Mol. Aspects Med. 29, 58-66 (2008)

171. Fernández, M. et al. Angiogenesis in liver disease. J. Hepatol. 50, 604-620 (2009).

172. Novo, E. et al. Cellular and molecular mechanisms in liver fibrogenesis. Arch. Biochem. Biophys. 548, 20-37 (2014).

173. Trautwein, C., Friedman, S. L., Schuppan, D. \& Pinzani, M. Hepatic fibrosis: concept to treatment. J. Hepatol. 62, S15-S24 (2015)

174. Lee, Y. A., Wallace, M. C. \& Friedman, S. L. Pathobiology of liver fibrosis: a translational success story. Gut 64, 830-841 (2015).

175. Nelson, C. J. et al. The chronology of depression and distress in men with peyronie's disease. J. Sex. Med. 5, 1985-1990 (2008).

176. Anaissie, J. et al. Peyronie's Disease. Urology 100 125-130 (2016).

177. Russo, G. I. et al. Clinical efficacy of injection and mechanical therapy for Peyronie's disease: a systematic review of the literature. Eur. Urol. https://doi.org/ 10.1016/j.eururo.2018.07.005 (2018).

178. Hinz, B. et al. The myofibroblast. Am. J. Pathol. 170, 1807-1816 (2007).

179. Hinz, B. et al. Recent developments in myofibroblast biology. Am. J. Pathol. 180, 1340-1355 (2012).

180. McAnulty, R. J. Fibroblasts and myofibroblasts: Their source, function and role in disease. Int. J. Biochem. Cell Biol. 39, 666-671 (2007).

181. Lamouille, S., Xu, J. \& Derynck, R. Molecular mechanisms of epithelial-mesenchymal transition. Nat. Rev. Mol. Cell. Biol. 15, 178-196 (2014).

182. Zavadil, J. \& Böttinger, E. P. TGF- $\beta$ and epithelialto-mesenchymal transitions. Oncogene $\mathbf{2 4}$ 5764-5774 (2005)

183. Kalluri, R. \& Neilson, E. G. Epithelial-mesenchymal transition and its implications for fibrosis. J. Clin. Invest. 112, 1776-1784 (2003).

\section{Author contributions}

All authors researched data for the article, made substantial contributions to the discussion of content, wrote the manuscript, and reviewed and edited the manuscript before submission.

\section{Competing interests}

The authors declare no competing interests.

\section{Publisher's note}

Springer Nature remains neutral with regard to jurisdictional claims in published maps and institutional affiliations.

\section{Reviewer information}

Nature Reviews Urology thanks I. Kovanecz and other anonymous reviewer(s) for their contribution to the peer review of this work. 